\title{
EUDESMANE AND REARRANGED EUDESMANE SESQUITERPENES FROM Nectandra cissiflora
}

\section{Fernanda R. Garcez*, Walmir S. Garcez, Lidilhone Hamerski e Ana Carolina de M. Miranda}

Departamento de Química, Centro de Ciências Exatas e Tecnologia, Universidade Federal de Mato Grosso do Sul, Av. Senador Filinto Muller, 1555, 79074-900 Campo Grande - MS, Brasil

Recebido em 12/2/10; aceito em 6/5/10; publicado na web em 24/8/10

\begin{abstract}
Four eudesmane-type sesquiterpenes, costic acid (1), 12-carboxyeudesman-3,11(13)-diene (2), viscic acid (3), 3-oxo- $\gamma$-costic acid (4) and two rearranged eudesmane derivatives, 3 $\alpha$-hydroxyisoiphion-11(13)-en-12-oic acid (5) and 5 $\beta$-hydroxy-4-oxo-11(13)dehydroiphionan-12-oic acid (6), in addition to (-)-epicatechin, have been isolated from the trunk bark of Nectandra cissiflora. This is the first reported occurrence in the Lauraceae of 3-6. The structures of the isolated compounds have been established on the basis of 1D and 2D NMR spectroscopic techniques. The ${ }^{13} \mathrm{C}$ NMR assignments of $\mathbf{3}, \mathbf{5}$ and $\mathbf{6}$ are given here for the first time, as well as some corrections to the previously reported chemical shift assignments of 4 .
\end{abstract}

Keywords: Nectandra cissiflora; Lauraceae; eudesmanes.

\section{INTRODUCTION}

Nectandra Rol. ex Rottb. is the second largest genus of the Lauraceae in the New World, being restricted to the tropical and subtropical Americas, where most of the species occurs between the tropics of Cancer and Capricorn. ${ }^{1}$ Forty-three species of this genus can be found in Brazil, mostly in the Atlantic Forest and Amazonia. ${ }^{2}$ On the other hand, Nectandra cissiflora Nees is a tree widely distributed in Brazil, where it is popularly known as "canela-fedida". To date, no phytochemical studies on Nectandra cissiflora have been reported, although this genus has been the subject of several chemical investigations, being mostly characterized by the presence of neolignans, lignans and aporphine alkaloids and also by terpenoids found in essential oils. ${ }^{3-5}$ Addingly, phenylpropanoids, sesquiterpenes and butanolides have also been shown to occur as nonvolatile constituents in a few members of Nectandra. ${ }^{4,6,7}$ Thus, as part of our ongoing study of Brazilian Lauraceae representatives growing in the "Cerrado" of the central-western region of Brazil, we have investigated the chemical composition of the trunk bark of $N$. cissiflora. Herein we report the isolation of four eudesmane- and two rearranged eudesmanetype sesquiterpene acids from this plant, in addition to (-)-epicatechin.

\section{EXPERIMENTAL}

\section{General experimental procedures}

${ }^{1} \mathrm{H}$ and ${ }^{13} \mathrm{C} 1 \mathrm{D}$ and 2D NMR spectra were recorded at $300 \mathrm{MHz}$ $\left({ }^{1} \mathrm{H}\right)$ and $75 \mathrm{MHz}\left({ }^{13} \mathrm{C}\right)$ on a Bruker DPX-300 spectrometer. Standard pulse sequences were used for homo - and heteronuclear correlation experiments. Column chromatography procedures were performed on silica gel 70-230 and 230-400 mesh, RP-18 silica gel 230-400 mesh and Sephadex LH-20. Reversed phase semi-preparative HPLC separations were performed with a Shimadzu LC-6AD pump, using RP18 and RP-8, 21.6 x $250 \mathrm{~mm}, 5 \mu \mathrm{m}$ particle size, Phenomenex Luna column, with a flow rate of $10 \mathrm{~mL} \mathrm{~min}^{-1}$ and monitoring at $210 \mathrm{~nm}$.

\section{Plant material}

The trunk bark of N. cissiflora was collected in Campo Grande, Mato Grosso do Sul, Brazil in August 2005 and identified by MSc.

\footnotetext{
*e-mail: frgarcez@nin.ufms.br
}

F. M. Alves (Departamento de Biologia, Universidade Federal de Mato Grosso do Sul, MS, Brazil). A voucher specimen (No. 11260) has been deposited at CGMS Herbarium (Universidade Federal de Mato Grosso do Sul, Campo Grande, MS, Brazil).

\section{Extraction and isolation of chemical constituents}

The air-dried and powdered trunk bark $(1.5 \mathrm{~kg})$ of $N$. cissiflora was exhaustively extracted with ethanol at room temperature and the combined extracts were concentrated in vacuo. The residue (115.0 g) was fractionated by CC on silica gel 70-230 mesh eluted successively with stepwise gradients of hexane, $\mathrm{CH}_{2} \mathrm{Cl}_{2}$, EtOAc and $\mathrm{MeOH}$ to yield 14 fractions $(\mathrm{A} \rightarrow \mathrm{O})$. Fraction $\mathrm{C}\left(8.46 \mathrm{~g}\right.$, hexane- $\left.\mathrm{CH}_{2} \mathrm{Cl}_{2} 1: 1\right)$ was again separated by $\mathrm{CC}$ on silica gel 70-230 mesh using a step gradient of increasing polarity: hexane- $\mathrm{CH}_{2} \mathrm{Cl}_{2}-\mathrm{EtOAc}-\mathrm{MeOH}$ to give a mixture $\left(104.0 \mathrm{mg}\right.$ ) of costic acid (1) ${ }^{8}$ and eudesma-3,11(13)dien-12-oic acid (2, minor component, also known as 3-isocostic acid). ${ }^{9}$ Compound $\mathbf{1}(13.2 \mathrm{mg})$ was again obtained from fraction $\mathrm{D}$ (1.1 g, hexane- $\left.\mathrm{CH}_{2} \mathrm{Cl}_{2} 1: 1\right)$, after $\mathrm{CC}$ on silica gel 230-400 mesh eluted with hexane to pure EtOAc, followed by RP-8 semipreparative HPLC $\left(\mathrm{CH}_{3} \mathrm{CN}-\mathrm{H}_{2} \mathrm{O}\right.$ 8:2). Fraction $\mathrm{G}$ (7.04 g, $\mathrm{CH}_{2} \mathrm{Cl}_{2}$-EtOAc 8:2) was fractionated on a RP-18 silica gel 230-400 mesh column eluted successively with stepwise gradients of $\mathrm{H}_{2} \mathrm{O}-\mathrm{MeOH}(8: 2,6: 4$, $4: 6,2: 8,1: 9,0.5: 9.5)$ and $\mathrm{MeOH}$ to yield seven fractions $(\mathrm{G} 1 \rightarrow \mathrm{G} 7)$. Fraction G3 (1.37 g) was rechromatographed on a RP-18 silica gel 230-400 mesh column with a gradient elution of $\mathrm{CH}_{3} \mathrm{CN}-\mathrm{H}_{2} \mathrm{O}$ 3:7 to pure $\mathrm{CH}_{3} \mathrm{CN}$ to furnish ten fractions $(\mathrm{G} 3-1 \rightarrow \mathrm{G} 3-10)$. Fraction G3-5 (116.2 mg) afforded an inseparable mixture (13.7 mg) of $5 \beta$-hydroxy-4-oxo-11(13)-dehydroiphionan-12-oic acid (5, major compound $)^{10}$ and $3 \alpha$-hydroxyisoiphion-11(13)-en-12-oic acid (6) ${ }^{11}$ after CC on silica gel 230-400 mesh using a gradient system of hexane $\rightarrow$ EtOAc $\rightarrow \mathrm{MeOH}$ as eluents, followed by $\mathrm{CC}$ on Sephadex $\mathrm{LH}-20(\mathrm{MeOH})$. Viscic acid $(3,15.0 \mathrm{mg})^{12}$ and a mixture $(25.0 \mathrm{mg})$ of 3 and 3-oxo- $\gamma$-costic acid (4, major component $)^{13}$ were obtained from fraction G3-10 (95.9 mg) after RP-8 semipreparative HPLC $\left(\mathrm{CH}_{3} \mathrm{CN}-\mathrm{H}_{2} \mathrm{O}-\mathrm{AcOH}\right.$ 3.5:6.45:0.05). (-)-Epicatechin (7, $8.3 \mathrm{mg}$ ) was isolated from fraction $\mathrm{N}$ after CC on Sephadex LH-20 (MeOH) followed by CC on silica gel 230-400 mesh eluted with hexane, EtOAc and $\mathrm{MeOH}$ by gradually increasing the polarity gradient.

Viscic acid (3): Oil. $[\alpha]_{\mathrm{D}}^{23}=-5.04\left(c 0.54, \mathrm{CHCl}_{3}\right) .{ }^{1} \mathrm{H}$ NMR $(300$ $\mathrm{MHz} \mathrm{CDCl}_{3}$ ) $\delta_{\mathrm{H}}: 6.29$ (s, H-13a), 5.65 (s, H-13b), 4.92 (br s, H- 
15a), 4.54 (br s, H-15b), 4.29 (br s, H-3), 2.55 (m, H-7), 2.41 (br d, $J=11.7, \mathrm{H}-5$ ), 1.77 (m, H-2), 1.73 (m, H-1a), 1.63 (m, H-8a), 1.62 (m, H-6a), 1.51 (m, H-9a), 1.45 (m, H-8b), 1.39 (m, H-9b), 1.24 (m, $\mathrm{H}-6 \mathrm{~b}), 1.23$ (m, H-1b), 0.70 (s, H-14). ${ }^{13} \mathrm{C} \mathrm{NMR} \mathrm{(75} \mathrm{MHz,} \mathrm{CDCl}_{3}$ ): $\delta_{\mathrm{C}} 172.0(\mathrm{C}-12), 151.5(\mathrm{C}-4), 145.1$ (C-11), 124.7 (C-13), 109.2 (C15), 73.5 (C-3), 43.7 (C-5), 40.6 (C-9), 39.3 (C-7), 35.8 (C-10), 35.6 (C-1), 29.6 (C-2, C-6), 27.1 (C-8), 15.5 (C-14).

3-Oxo- $\gamma$-costic acid (4): ${ }^{1} \mathrm{H}$ NMR $\left(300 \mathrm{MHz}, \mathrm{CDCl}_{3}\right) \delta_{\mathrm{H}}: 6.36$ (s, H-13a), 5.71 (s, H-13b), 2.83 (br d, $J=13.5 \mathrm{~Hz}, \mathrm{H}-6 \mathrm{a}), 2.55$ (m, H-7), 2.48 (m, H-2), 2.02 (br t, $J=13.5, \mathrm{H}-6 \mathrm{~b}$ ), 1.74 (s, H-15), 1.73 (m, H-9a), 1.70 (m, H-1), 1.68 (m, H-8a), 1.66 (m, H-9b), 1.45 (m, $\mathrm{H}-8 \mathrm{~b}), 1.21$ (s, H-14). ${ }^{13} \mathrm{C}$ NMR (75 MHz, $\left.\mathrm{CDCl}_{3}\right)$ : $\delta_{\mathrm{C}} 199.4(\mathrm{C}-3)$, 171.4 (C-12), 161.4 (C-5), 143.9 (C-11), 129.1 (C-4), 125.4 (C-13), 41.7 (C-9), 39.7 (C-7), 37.3 (C-1), 35.8 (C-10), 33.7 (C-2), 33.3 (C6), 27.1 (C-8), 22.4 (C-14), 10.9 (C-15).

5ß-hydroxy-4-oxo-11(13)-dehydroiphionan-12-oic acid $(\mathbf{5}):{ }^{1} \mathrm{H}$ NMR (300 MHz, CD OD) $\delta_{\mathrm{H}}: 5.85$ (s, H-13a), 5.28 (s, H-13b), 3.58 (dd, $J=9.8,7.7, \mathrm{H}-3$ ), 2.81 (br t, $J=12.0, \mathrm{H}-7), 2.23$ (s, H-15), 2.20 (m, H-2a), 1.90 (m, H-2b), 1.85 (m, H-6a), 1.65 (m, H-8a), 1.45 (m, H-6b), 1.40 (m, H-8b), 0.98 (s, H-14). ${ }^{13} \mathrm{C}$ NMR (75 MHz, CD $\mathrm{OD}): \delta_{\mathrm{C}} 213.5$ (C-4), 175.1 (C-12), 151.8 (C-11), 117.6 (C-13), 84.8 (C-5), 57.3 (C-3), 47.6 (C-10), 38.6* (C-1), 38.4* (C-9), 38.0 (C-7), 37.4 (C-6), 31.6 (C-15), 28.6 (C-8), 23.3 (C-2), 19.1 (C-14); *interchangeable signals.

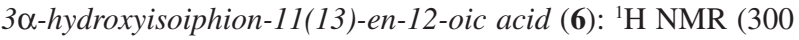
$\left.\mathrm{MHz}, \mathrm{CD}_{3} \mathrm{OD}\right) \delta_{\mathrm{H}}: 5.82$ (s, H-13a), 5.31 (s, H-13b), 4.36 (dd, $J=$ 8.4, 4.3, H-3), 3.20 (m, H-7), 2.25 (m, H-6a), 2.15 (s, H-15), 2.15 (m, H-2a), 1.90 (m, H-2b), 1.75 (m, H-6b), 1.60 (m, H-8a), 1.50 (m, $\mathrm{H}-8 \mathrm{~b}), 0.98$ (s, H-14). ${ }^{13} \mathrm{C}$ NMR $\left(75 \mathrm{MHz}, \mathrm{CD}_{3} \mathrm{OD}\right): \delta_{\mathrm{C}} 217.0(\mathrm{C}-4)$, 175.1 (C-12), 153.1 (C-11), 117.6 (C-13), 80.1 (C-3), 65.9 (C-5), 44.6 (C-10), 38.7* (C-9), 38.3* (C-1), 37.3 (C-7), 33.9 (C-6), 33.0 (C-2), 30.2 (C-15), 27.7 (C-8), 23.0 (C-14); *interchangeable signals.

\section{RESULTS AND DISCUSSION}

The ${ }^{1} \mathrm{H}$ and ${ }^{13} \mathrm{C}$ NMR spectroscopic data of compound $\mathbf{1},[\alpha]_{\mathrm{D}}^{23}=+$ 13.0 ( $c 0.30, \mathrm{CHCl}_{3}$ ), were in good agreement with those reported for costic acid, a eudesmane sesquiterpene which was previously isolated from a few members of the Lauraceae, as well as from other plant families ${ }^{4,7,8,14}$ The ${ }^{1} \mathrm{H}$ NMR spectrum of $\mathbf{1}$ was characterized by the presence of the $\mathrm{C}-14$ methyl singlet at $\delta 0.76$, two singlets assigned to the hydrogens of the double bond conjugated to the carboxyl group at C-11 (13) and another two singlets attributed to the exocyclic olefinic hydrogens at $\mathrm{C}-15$. In the ${ }^{13} \mathrm{C}$ NMR spectrum, resonances for $\mathrm{C}-14$, C-11, C-13, C-4 and C-15 were observed at $\delta 16.4,145.4,124.6$, 150.6 and 105.5, respectively. Sesquiterpene 1 was also obtained in the present work as an inseparable mixture with compound 2 . In the ${ }^{1} \mathrm{H}$ and ${ }^{13} \mathrm{C}$ NMR spectra of this mixture, the signals corresponding to compound 1 were readily discernible and the remaining ones, which were attributed to compound $\mathbf{2}$, indicated that their structures only differed in the position of the non-conjugated double bond, which was located at $\mathrm{C}-3$ in the skeleton of the latter. This assumption could be inferred by the presence of a vinyl methyl singlet at $\delta_{\mathrm{H}} 1.59 / \delta_{\mathrm{C}} 21.1$ and a signal ascribed to an olefinic hydrogen at $\delta 5.31$, together with the carbon resonances of a trisubstituted double bond at $\delta 121.0(\mathrm{CH})$ and $\delta 134.7$ (C). The spectral data of $\mathbf{2}$ were in complete agreement with those reported for eudesma-3,11(13)-dien-12-oic acid isolated from Dittrichia graveolens (Asteraceae). ${ }^{9}$

Comparison of NMR data of $\mathbf{3}$ with those of $\mathbf{1}$ revealed that they are closely related. The only difference refers to the presence of a hydroxyl function, on the basis of a broad singlet at $\delta 4.29$ in the ${ }^{1} \mathrm{H}$ NMR spectrum of $\mathbf{3}$, attributable to the carbinolic hydrogen which correlated in the HSQC spectrum with a signal at $\delta 73.5$. The location
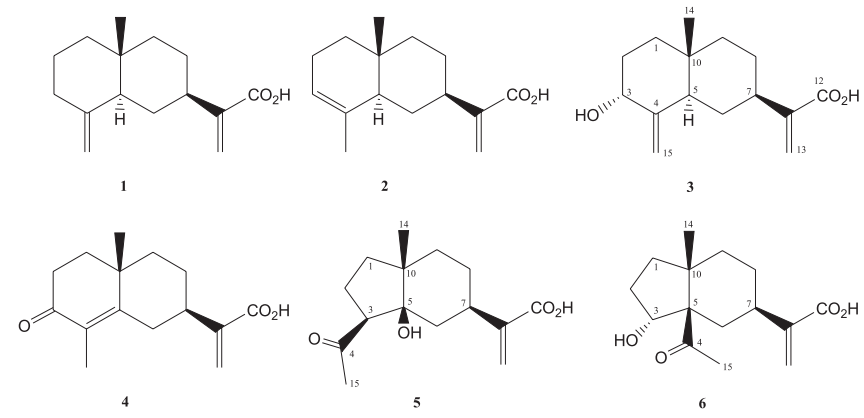

Figure 1. Chemical structures of sesquiterpenes isolated from the trunk bark of $N$. cissiflora

of the hydroxyl group at $\mathrm{C}-3$ in $\mathbf{3}$ was supported by the long-range correlations observed in the $\mathrm{HMBC}$ spectrum between $\mathrm{H}-3$ and the carbons at $\delta 35.6\left(\mathrm{C}-1,{ }^{3} \mathrm{~J}\right), 43.7\left(\mathrm{C}-5,{ }^{3} \mathrm{~J}\right), 109.1\left(\mathrm{C}-15,{ }^{3} \mathrm{~J}\right)$ and 151.4 $\left(\mathrm{C}-4,{ }^{2} J\right)$. The appearance of $\mathrm{H}-3$ as a broad singlet determined its equatorial position and the resulting $\alpha$-orientation for the hydroxyl group. Further evidence for this assumption was provided by the upfield shifted C-1 and C-5 resonances in 3 ( $\delta 35.6$ and 43.7) as compared to the chemical shift values of the corresponding carbons in $\mathbf{1}(\delta$ 41.8 and 49.9, respectively), due to the $\gamma$-effect of the hydroxyl at C-3. Thus, the structure of $\mathbf{3}$ was assigned as shown and its ${ }^{1} \mathrm{H}$ NMR data were in good accordance with those reported for $3-\alpha$ hydroxycostic acid, also known as viscic acid, a sesquiterpene obtained from Dittrichia viscosa (Asteraceae). ${ }^{12}$ Unambiguous assignment of ${ }^{13} \mathrm{C}$ NMR data for $\mathbf{3}$ and not yet published is here presented for the first time.

Compound $\mathbf{4}$ was isolated as the main component of an unresolvable mixture with 3. Comparison of the ${ }^{1} \mathrm{H}$ and ${ }^{13} \mathrm{C}$ NMR signals attributed to $\mathbf{4}$ with those of $\mathbf{3}$ showed that the differences in their proton and carbon resonances could be accounted for by the absence of the hydroxyl group, which was replaced by a carbonyl function in $\mathbf{4}$ and the presence of a $\mathrm{C}_{4}-\mathrm{C}_{5}$ double bond in $\mathbf{4}$ instead of the $\mathrm{C}_{4}-\mathrm{C}_{15}$ exocyclic double bond in $\mathbf{3}$. This proposal was based on the signals attributed to a ketone carbonyl at $\delta 199.4$ and a tetrasubstituted conjugated double bond at $\delta_{\mathrm{C}} 129.1$ and 161.4 , in addition to a signal ascribed to a vinylic methyl at $\delta_{\mathrm{H}} 1.74 / \delta_{\mathrm{C}} 10.9$. The connectivities observed in the HMBC spectrum between the methyl hydrogens $\mathrm{H}_{3}-15(\delta 1.74)$ and the carbonyl carbon $(\delta 199.4)$ and between $\mathrm{H}_{3}-$ $15 / \mathrm{H}_{3}-14(\delta 1.21)$ and the olefinic carbon assigned to $\mathrm{C}-4(\delta 161.4)$ confirmed the location of the tetrasubstituted double bond between C-4 and C-5. In the ${ }^{13} \mathrm{C}$ NMR spectrum, the chemical shift of C-15 ( $\delta$ 10.9) as compared to that of $\mathrm{C}-15$ in compound 2 ( $\delta 21.1)$ might be due to the $\gamma$-effect of the carbonyl at C-3 in 4 . The unequivocal assignments of the remaining carbon resonances of $\mathbf{4}$ were based on the correlations observed in the HSQC and HMBC spectra. Therefore, compound 4 was identified as 3-oxo-4,11(13)-eudesmadien-12-oic acid, also known as 3-oxo- $\gamma$-costic acid, which was previously characterized in Varthemia iphionoides ${ }^{13}$ and also in other members of the Asteraceae. However, the previous chemical shift assignments reported for the carbon resonances C-1, C-8, C-9, C-14 and C-15 13 and C-1, C-2, C-6 and C-8 ${ }^{15}$ of 3-oxo- $\gamma$-costic acid should be corrected and have thus been reassigned in the present work.

Compounds $\mathbf{5}$ and $\mathbf{6}$ were isolated as an unresolved mixture, in which the first was found to be the major component. The signals observed in the ${ }^{1} \mathrm{H}$ and ${ }^{13} \mathrm{C}$ NMR spectra of the mixture were similar to those of the sesquiterpenes 1-4, particularly the ones attributed to the hydrogens and carbons of the ring B and the side chain at C-7. Accordingly, the singlets at $\delta_{\mathrm{H}} 5.28$ and 5.85 were ascribed to the olefinic hydrogens $\mathrm{H}-13$ of $\mathbf{5}$, whose olefinic carbons $\mathrm{C}-11$ and $\mathrm{C}-13$ and the carboxyl group at C-12 resonated at $\delta 151.8,117.6$ and 175.1, respectively, in the ${ }^{13} \mathrm{C}$ NMR spectrum. These spectra also showed 
characteristic signals of an acetyl moiety in the skeleton of $\mathbf{5}$, namely one methyl singlet at $\delta_{\mathrm{H}} 2.23$ and a carbonyl carbon signal at $\delta_{\mathrm{C}} 213.5$. Accordingly, in the HSQC and HMBC spectra the aforementioned methyl singlet showed cross-correlation peaks with the signals at $\delta_{C}$ 31.6 and 213.5, respectively. Other signals ascribed to 5 in the ${ }^{1} \mathrm{H}$ and ${ }^{13} \mathrm{C}$ NMR spectra of the mixture were those corresponding to another methyl singlet at $\delta_{\mathrm{H}} 0.98 / \delta_{\mathrm{C}} 19.1$ and a quaternary oxygenated carbon at $\delta_{C}$ 84.8. This information, together with those provided by the DEPT spectrum, suggested the molecular formula $\mathrm{C}_{15} \mathrm{H}_{22} \mathrm{O}_{4}$ for compound 5, thus indicating a bicarbocyclic skeleton for this sesquiterpene bearing a five-membered A ring. The acetyl residue was shown to be linked at $\mathrm{C}-3$, on the basis of connectivities observed in the HSQC and HMBC spectra and so the structure of $\mathbf{5}$ was related to an iphionane-type sesquiterpene. Thus, the double doublet ascribed to $\mathrm{H}-3$ at $\delta 3.58(J=9.8$ and $7.7 \mathrm{~Hz})$, which was shown to be linked to the carbon at $\delta 57.3$ in the HSQC spectrum, showed connectivities in the HMBC spectrum with the signals ascribed to the carbonyl carbon at $\delta_{\mathrm{C}} 213.5$, the oxygenated quaternary carbon at $\delta_{\mathrm{C}} 84.8$ and a methylene carbon at $\delta_{C} 23.3$. These data were in accordance with the linkage of the acetyl group at C-3 and also with the presence of a hydroxyl function at C-5. This assumption was proved to be correct by the long-range correlation between the methyl hydrogens of the acetyl group and the methylene carbon at $\delta_{\mathrm{C}} 23.3$, which was thus ascribed to C-2, as well as by the connectivity between the methyl-14 hydrogens at $\delta_{\mathrm{H}} 0.98$ and C-5 $\left(\delta_{\mathrm{C}} 84.8\right)$. Therefore, the structure of 5 was shown to be identical to the iphionane-type sesquiterpene $5 \beta$-hydroxy-4-oxo-11(13)-dehydroiphionan-12-oic acid, previously isolated from a species of Asteraceae (Jasonia candicans), but nevertheless with no information available on its NMR spectroscopic data. ${ }^{10}$ However, the ${ }^{1} \mathrm{H}$ NMR data of $\mathbf{5}$ were in agreement with those of its corresponding methyl ester derivative, which was obtained from another member of the Asteraceae (Ursinia eckloniana) ${ }^{16}$ and thus allowed us to confirm the structure of $\mathbf{5}$ as shown. The ${ }^{13} \mathrm{C} \mathrm{NMR}$ data of $\mathbf{5}$, which were unequivocally assigned in the present work, are being reported for the first time.

The remaining signals in the ${ }^{1} \mathrm{H}$ and ${ }^{13} \mathrm{C}$ NMR of the mixture were assigned to its minor component $\mathbf{6}$, which was also shown to have a rearranged-type sesquiterpene skeleton. Comparison of NMR data of $\mathbf{6}$ with those of $\mathbf{5}$ revealed that the only difference was that the hydroxyl group at C-5 and the acetyl moiety at C-3 in $\mathbf{5}$ changed places with each other in $\mathbf{6}$. This could be inferred by the presence of a double doublet at $\delta 4.36(J=8.4$ and $4.3 \mathrm{~Hz})$, which showed correlation with the signal of a carbinolic carbon at $\delta 80.1$ in the HSQC spectrum and was assigned to $\mathrm{H}-3$. In addition, the quaternary carbon resonance at $\delta 65.9$ was attributed to $C-5$ on the basis of the correlation observed in the HMBC spectrum between this carbon and the methyl hydrogens $\mathrm{H}-14$ at $\delta 0.98$, which in turn showed correlation to $\mathrm{C}-10$ $(\delta$ 44.6). Cross-peak correlations were also observed between the acetyl methyl ( $\delta 2.15)$ and C-5 and C-4 carbonyl ( $\delta$ 217.0). The ${ }^{1} \mathrm{H}$ NMR data of 6 were in accordance with those previously described for 3 $\alpha$-hydroxyisoiphion-11(13)-en-12-oic acid, which was isolated as its methyl ester derivative from Dittrichia viscosa (Asteraceae). ${ }^{11}$ Its ${ }^{13} \mathrm{C}$-NMR assignments were not reported in the literature and so are provided in the present work.

The co-occurrence in N. cissiflora of the iphionane- and isoiphionane-type sesquiterpenes 5 and $\mathbf{6}$ and eudesmanes 1-4 reinforces the suggested biogenetic inter-relationship between those relatively small group of naturally occurring rearranged sesquiterpenes and eudesmanes. ${ }^{17}$ Thus, compound $\mathbf{5}$, which might have been formed by oxidative cleavage of C-4/C-5 bond of an eudesmane-type sesquiterpene precursor [eudesma-4,11(13)-diene-12-oic acid] leading to a 4,6-diketo derivative, followed by aldol condensation between $\mathrm{C}-3$ and $\mathrm{C}-5$, is thus being reported for the first time in the Lauraceae.
Compound 6, which is also being reported for the first time in the Lauraceae, might have been originated, in a similar fashion as $\mathbf{5}$, by oxidative cleavage of $\mathrm{C} 3 / \mathrm{C}-4$ bond of $\mathbf{2}$, followed by aldol condensation between $\mathrm{C}-3$ and $\mathrm{C}-5$ of the dicarbonyl derivative.

\section{CONCLUSION}

Although sesquiterpenes have been found in several species of the Lauraceae, mainly as components of leaf essential oils, only three representatives of this class of compounds have been described so far as non-volatile constituents in members of the genus Nectandra, namely 3 -isocostic acid and ilicic acid in N. membranace $a^{4}$ and costic acid in $N$. grandiflora and $N$. membranacea, ${ }^{4,7}$ and so the chemotaxonomic importance of the sesquiterpenoids obtained from $N$. cissiflora in the present work deserves consideration. Noteworthy is the first reported occurrence in the Lauraceae of 3-6, sesquiterpenes which were previously found as constituents of species of the Asteraceae. Also worthy of mentioning is that sesquiterpene acids bearing rearranged eudesmane skeletons of the iphionane- and isoiphionane-types like those depicted by $\mathbf{5}$ and $\mathbf{6}$, respectively, are scarcely distributed in plants. On the other hand, aporphine alkaloids, neolignans and lignans, which represent the major classes of secondary metabolites isolated from members of Nectandra, have not been detected in the specimen of $N$. cissiflora investigated in the present work.

\section{SUPPLEMENTARY MATERIAL}

${ }^{1} \mathrm{H}$ NMR, ${ }^{13} \mathrm{C}$ NMR, HSQC and HMBC spectra of compounds 1-6 are available free of charge at http://quimicanova.sbq.org.br as a PDF file.

\section{ACKNOWLEDGMENTS}

The authors are grateful to FUNDECT-MS, CPq-PROPP-UFMS and PROAP-CAPES for their financial support and to CNPq and CAPES for the scholarships awarded. Thanks are also given to MSc. F. M. Alves (Departmento de Biologia, Universidade Federal de Mato Grosso do Sul, MS, Brazil) for his assistance in the identification of the plant material.

\section{REFERENCES}

1. van der Werff, H.; Ann. Missouri Bot. Gard. 1991, 78, 377.

2. Baitello, J. B.; Hernandez, F. L.; Moraes, P. L. R.; Esteves, R.; Marcovino, J. R. In Flora Fanerogâmica do Estado de São Paulo; Wanderley, M. G. L.; Shepherd, G. J.; Melhem, T. S.; Giulietti, A. M.; Kirizawa, M., eds.; RiMa/FAPESP: São Paulo, 2003, vol. 3, p. 149.

3. Barrera, C. E. D.; Suarez, L. E. C.; Chem. Pharm. Bull. 2009, 57, 639; Barbosa Filho, J. M.; Yoshida, M.; Gottlieb, O. R.; Phytochemistry 1989, 28, 1991; Carvalho, M. G.; Yoshida, M.; Gottlieb, O. R.; Gottlieb, H. E.; Phytochemistry 1987, 26, 265; Castro, O.; Hasbun, C.; Calderon, M.; Fitoterapia 1991, 62, 72; Cherigo, L.; Polanco, V.; Ortega-Barria, E.; Heller, M. V.; Capson, T. L.; Rios, L. C.; Nat. Prod. Res. 2005, 19, 373; Silva, A. A.; Albuquerque, S.; Silva, M. L. A. E.; Eberlin, M. N.; Tomazela, D. M.; Bastos, J. K.; J. Nat. Prod. 2004, 67, 42.

4. Wu, X.; Vogler, B., Haber; W. A., Setzer, W. N.; Nat. Prod. Comm. 2006, 1,465 .

5. Ciccio, J. F.; Chaverri, C.; Diaz, C.; Quim. Nova 2009, 32, 417.

6. Garcez, F. R.; Garcez, W. S.; Hamerski, L.; Miguita, C. H.; Quim. Nova 2009, 32, 407; Garcez, F. R.; Garcez, W. S.; Martins, M.; Cruz, A. C.; Planta Med. 1999, 65, 775; Suarez, M.; Bonilla, J.; De Diaz, A. M. P.; Achenbach, H.; Phytochemistry 1983, 22, 609; Roque, N. F.; Gottlieb, O. R.; Coxon, D. T.; Phytochemistry 1977, 16, 257. 
7. Moreno, P. R. H.; von Poser, G. L.; Rates, S. M. K.; Yoshida, M.; Gottlieb, O. R.; Souza, I. A.; Henriques, A. T.; Int J. Pharmacog. 1993, $31,189$.

8. Watanabe, Y.; Mihara, R.; Mitsunaga, T.; Yoshimura, T.; J. Wood Sci. 2005, 51, 514

9. Lanzetta, R.; Lama, G.; Mauriello, G.; Parrilli, M.; Racioppi, R.; Sodano, G.; Phytochemistry 1991, 30, 1121

10. Ahmed, A. A.; Mahmoud, A. A.; Tetrahedron 1998, 54, 8141.

11. Rustaiyan A.; Jakupovic J.; Chau-Thi T. V.; Bohlmann F.; Sadjadi A.; Phytochemistry 1987, 26, 2603.

12. Ceccherelli, P.; Curini, M.; Marcotullio, M. C.; Menghini, A.; Phytochemistry 1985, 24, 2987.

13. Al-Dabbas, M. M.; Maher, M.; Hashinaga, F.; Abdelgaleil, S. A. M.; Suganuma, T.; Akiyama, K.; Hayashi, H.; J. Ethnopharmacol. 2005, 97 , 237.
14. Cheng, W.; Zhu, C.; Xu, W.; Fan, X.; Yang, Y.; Li, Y.; Chen, X.; Wang, W.; Shi, J.; J. Nat. Prod. 2009, 72, 2145.

15. Sanz, M. B. K.; Donadel, O.; J. Plant Cell Tissue Organ Cult. 2003, 73, 123.

16. Jakupovic, J.; Ganzer, U.; Pritschow, P.; Lehmann, L.; Bohlmann, F.; King, R. M.; Phytochemistry 1992, 31, 863.

17. Todorova, M. N.; Tsankova, E. T.; Phytochemistry 1999, 52, 1515; Coates, R. M. In Progress in the Chemistry of Organic Natural Products; Herz, W.; Grisebach, H.; Kirby, G. W., eds.; Springer-Verlag: Berlin, 1976, vol. 33, p. 73; Hikino, H. ; Kohama, T.; Takemoto, T.; Tetrahedron 1969, 25, 1037. 


\section{EUDESMANE AND REARRANGED EUDESMANE SESQUITERPENES FROM Nectandra cissiflora}

Fernanda R. Garcez*, Walmir S. Garcez, Lidilhone Hamerski e Ana Carolina de M. Miranda

Departamento de Química, Centro de Ciências Exatas e Tecnologia, Universidade Federal de Mato Grosso do Sul, Av. Senador Filinto Muller, 1555, 79074-900 Campo Grande - MS, Brasil

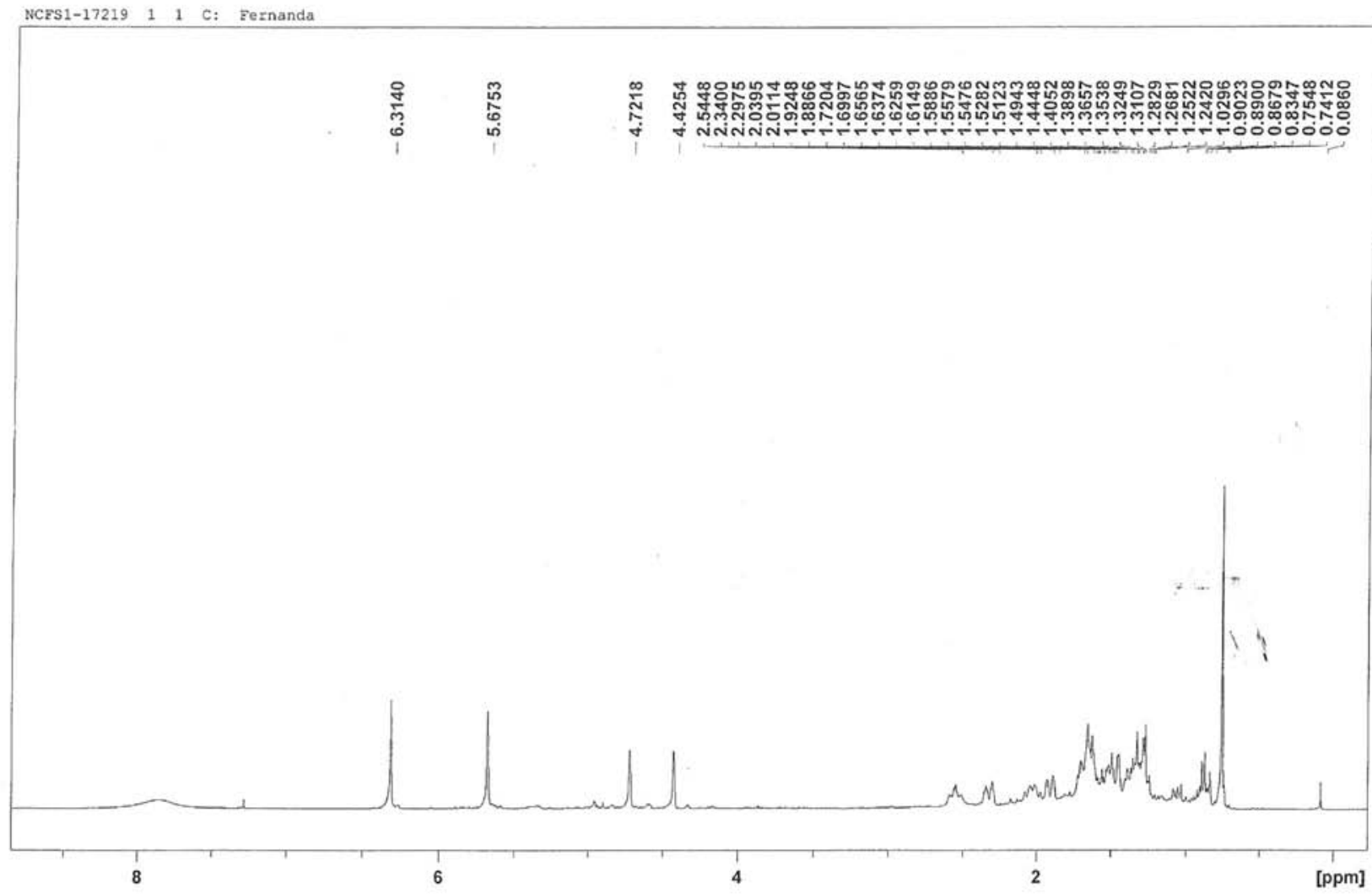

Figure 1S. ${ }^{l} \mathrm{H} \mathrm{NMR}\left(300 \mathrm{MHz}, \mathrm{CDCl}_{3}\right)$ of compound 1 (costic acid) 


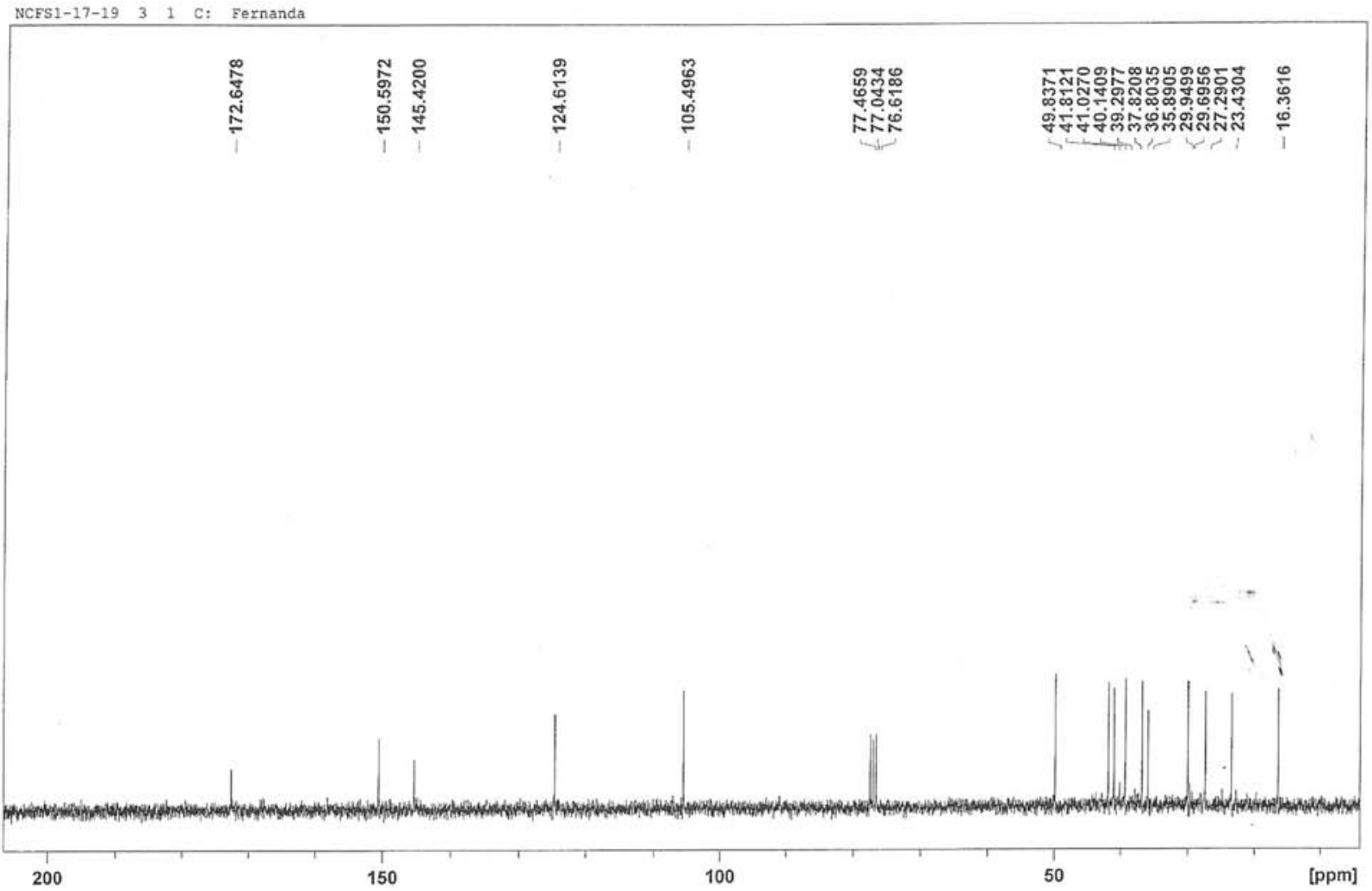

Figure 2S. ${ }^{13} \mathrm{C} \mathrm{NMR}\left(75 \mathrm{MHz}, \mathrm{CDCl}_{3}\right)$ of compound $\mathbf{1}$ (costic acid)

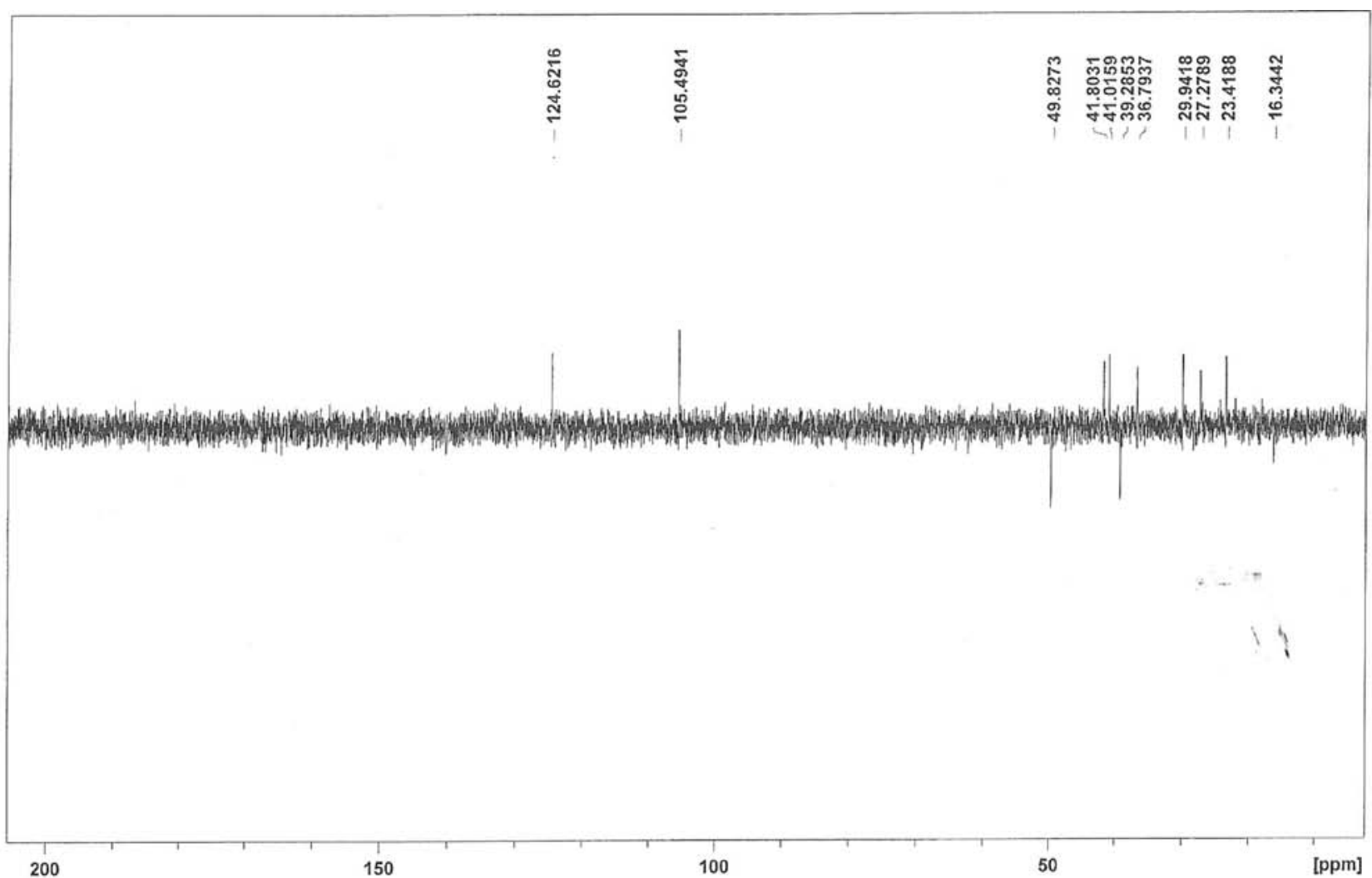

Figure 3S. DEPT $135^{\circ}\left(75 \mathrm{MHz}, \mathrm{CDCl}_{3}\right)$ of compound $\mathbf{1}$ (costic acid) 


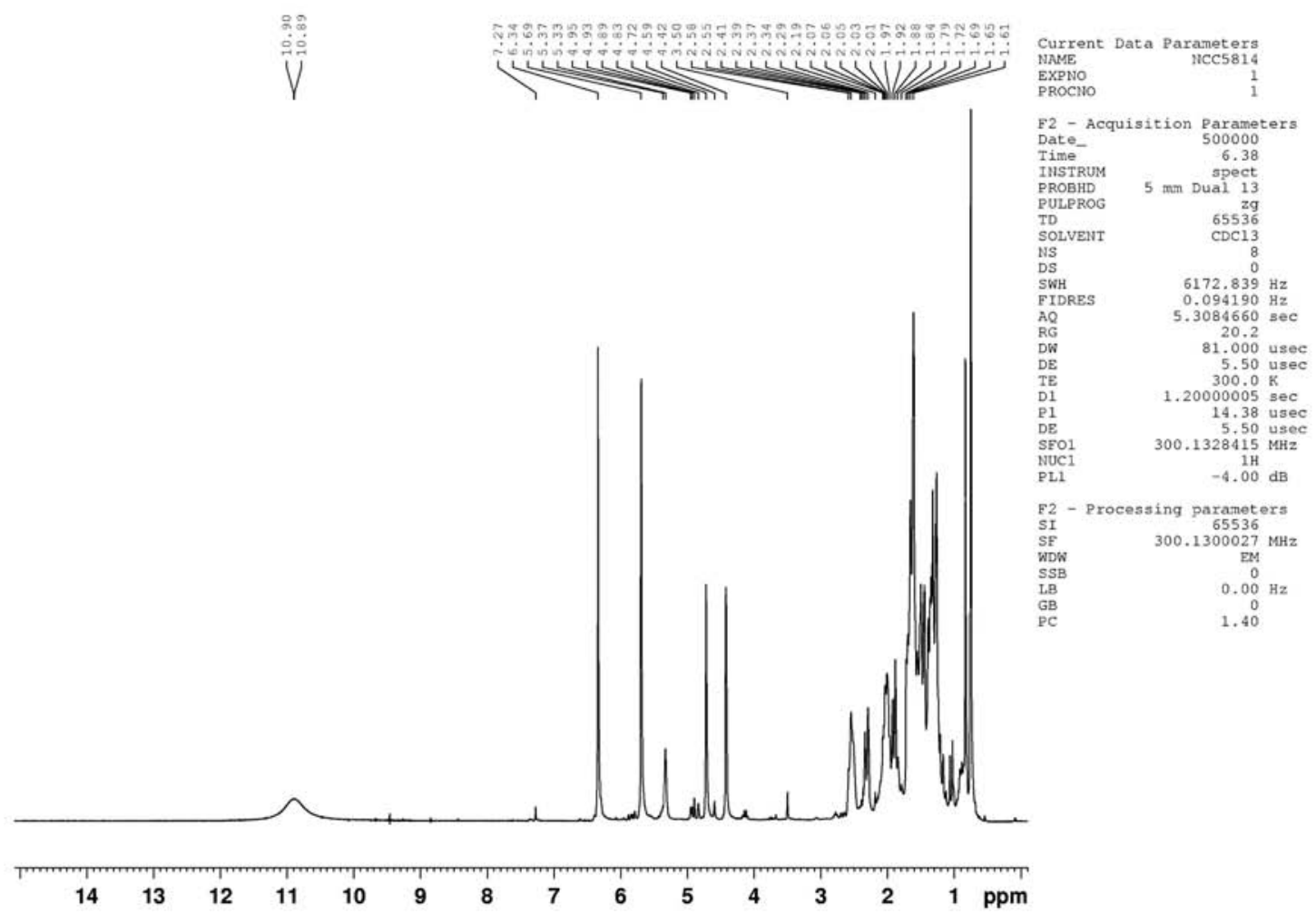

Figure 4S. ${ }^{1} \mathrm{H} N \mathrm{NMR}\left(300 \mathrm{MHz}, \mathrm{CDCl}_{3}\right)$ of compounds $\mathbf{1}+\mathbf{2}$ [costic acid and eudesma-3,11 (13)-dien-12-oic acid]
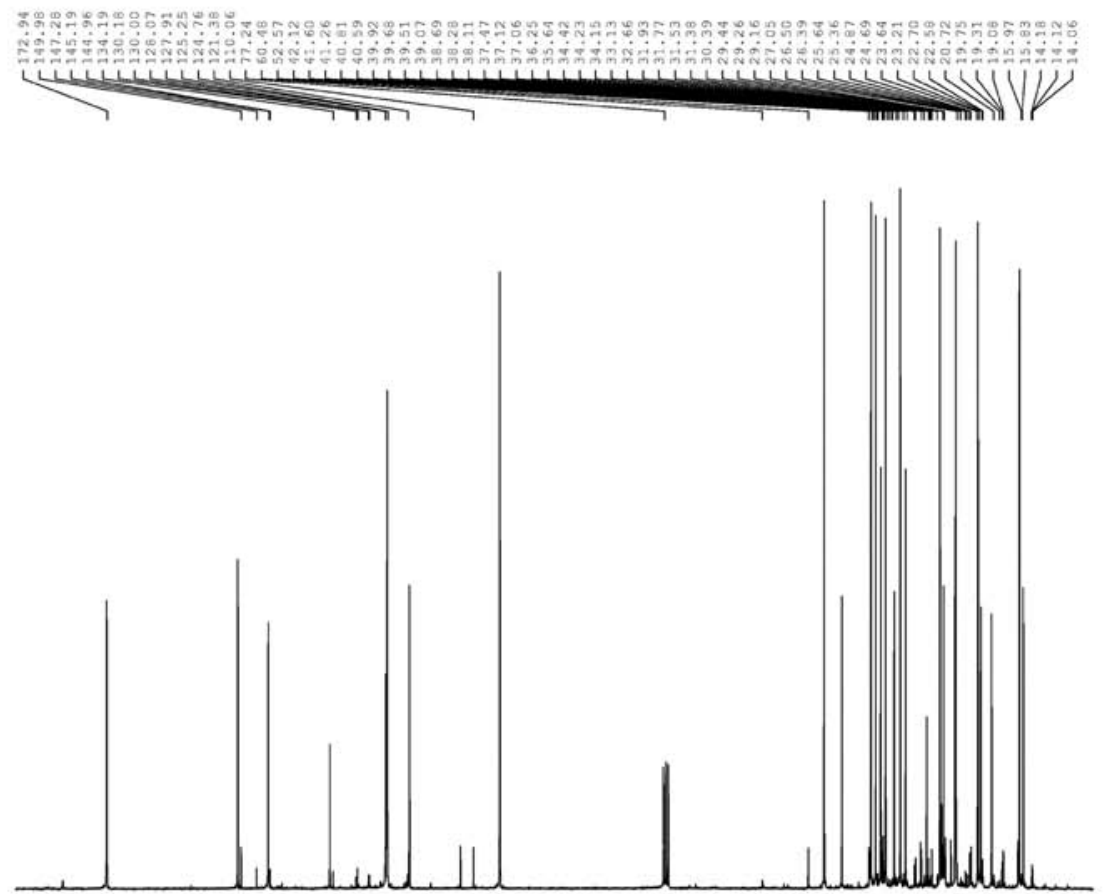

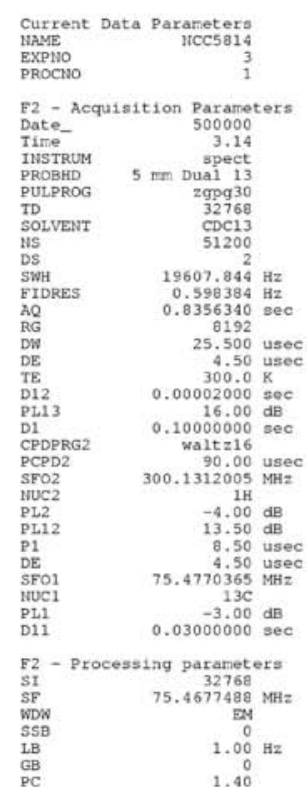

$$
\begin{aligned}
& \begin{array}{lr}
\text { Time- } & 3.14 \\
&
\end{array} \\
& \text { PROBHD } \quad 5 \mathrm{~mm} \text { Dual } 13 \\
& \begin{array}{l}
\quad 32768 \\
\text { TD OLVENT } \\
\text { CDC13 }
\end{array} \\
& \begin{array}{lr}
19607.844 \mathrm{~Hz} \\
\text { SWH } & 0.598384 \mathrm{~Hz}
\end{array} \\
& \text { IDRES } \quad 0.83563402 \\
& \begin{array}{rr}
65.500 \\
\text { usec }
\end{array} \\
& 12 \quad 0.00002000 \mathrm{sec} \\
& \begin{array}{ll}
01 & 16.00 \mathrm{~dB} \\
\mathrm{D} 1 & 0.10000000 \mathrm{sec}
\end{array} \\
& \begin{array}{ll}
\text { CPDPRG2 } & \text { waltz16 } \\
90.00 & \text { usec }
\end{array} \\
& \text { SFO2 } \quad 300.1312005 \mathrm{MHz} \\
& \begin{array}{ll}
-4.00 \mathrm{~dB} \\
\mathrm{PL2} 2 & 13.50 \mathrm{~dB}
\end{array} \\
& \begin{array}{rr}
8.50 \text { usec } \\
\text { Fo1 } & 4.50 \text { usez } \\
& 75.4770365 \\
\hline \text { MHz }
\end{array} \\
& \text { C1 } 13 \mathrm{C} \\
& 2 \text { - Processing paraneters } \\
& \begin{array}{lc}
\text { SI } & 32768 \\
\text { SF } & 75.467748 \mathrm{MHz} \\
\text { WDW } & \text { EN } \\
\text { SSB } & 0 \\
\text { LB } & 1.00 \mathrm{~Hz} \\
\text { GB } & 0 \\
\text { PC } & 1.40
\end{array}
\end{aligned}
$$



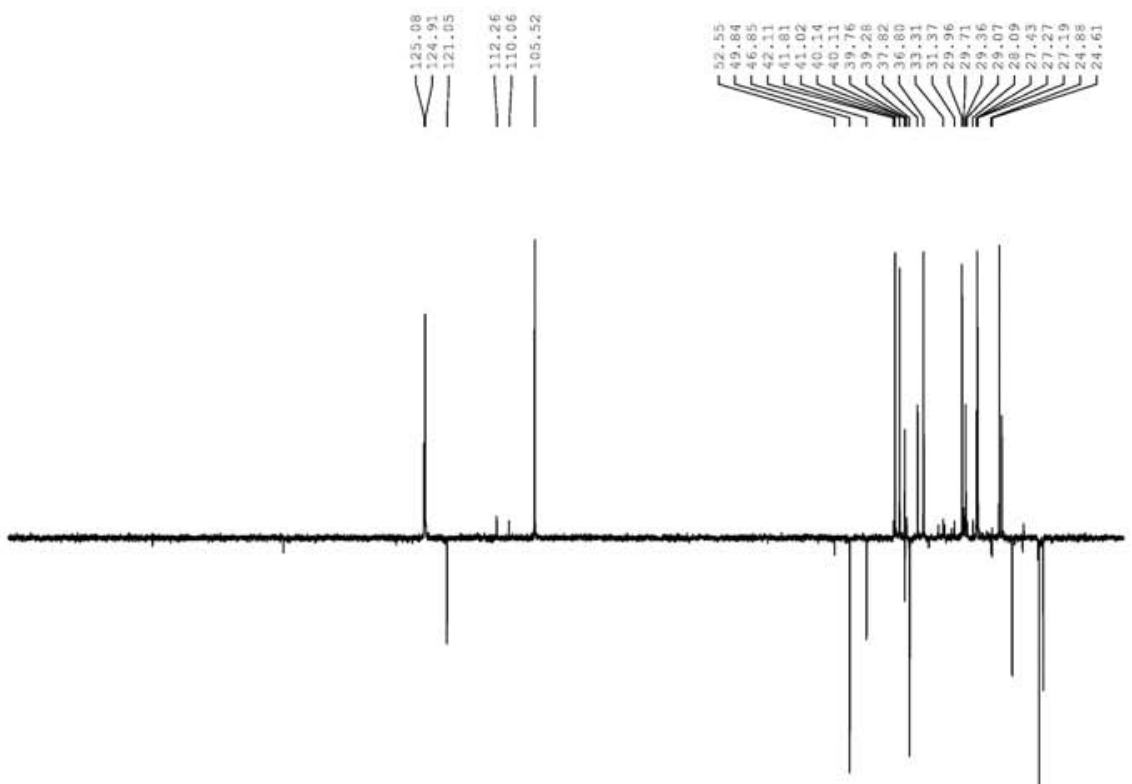

Current Data Parareters
WCC581 EXP1D

F2 - Acquisition Parameters
Date-

Time-

INSTRUM

PROBHD

TULPROG

LIVENT

DS

SWH
FIDRES
AQ

DW

TE

ELTA

$\mathrm{D} 112$
$\mathrm{D} 12$
$\mathrm{PL2}$
$\mathrm{P} 3$

$\mathrm{P} 3$
$\mathrm{SFO} 2$

NUC2 2
$\mathrm{D} 2$

P4
SFO1
nUC1

PL1
P2
PL12

PL12
DE
CPDPRG

CPDPRG2
PCPD2

$\begin{array}{lr}\text { F2 } & \text { Processing parameters } \\ \text { SI } & 32768 \\ \text { SE } & 75.4677494 \mathrm{MHz} \\ \text { WDW } & \mathrm{EM} \\ \text { SSB } & 0 \\ \text { LB } & 1.00 \mathrm{~Hz}\end{array}$

SSB
IB
GB
PC

1.00
0
1.40

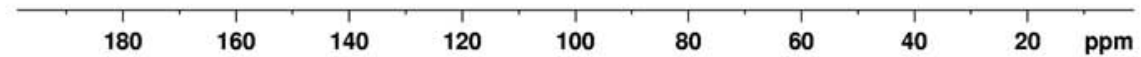

Figure $\mathbf{6 S}, \mathrm{DEPT} 135^{\circ}\left(75 \mathrm{MHz}, \mathrm{CDCl}_{3}\right)$ of compounds $\mathbf{1}+\mathbf{2}$ [costic acid and eudesma-3,11 (13)-dien-12-oic acid]

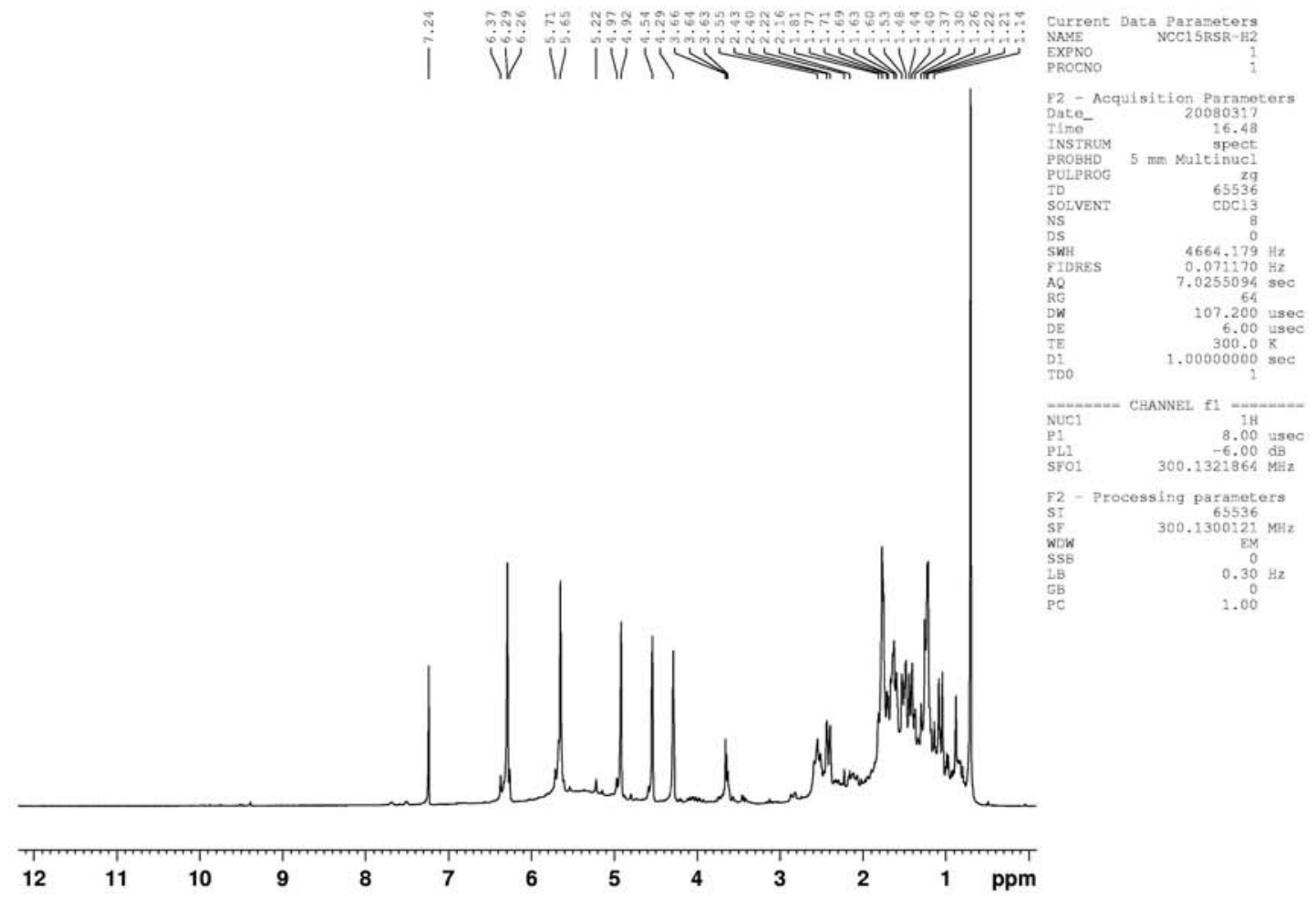

Figure 7S. ${ }^{1} \mathrm{H} \mathrm{NMR}\left(300 \mathrm{MHz}, \mathrm{CDCl}_{3}\right)$ of compound $\mathbf{3}$ (viscic acid) 


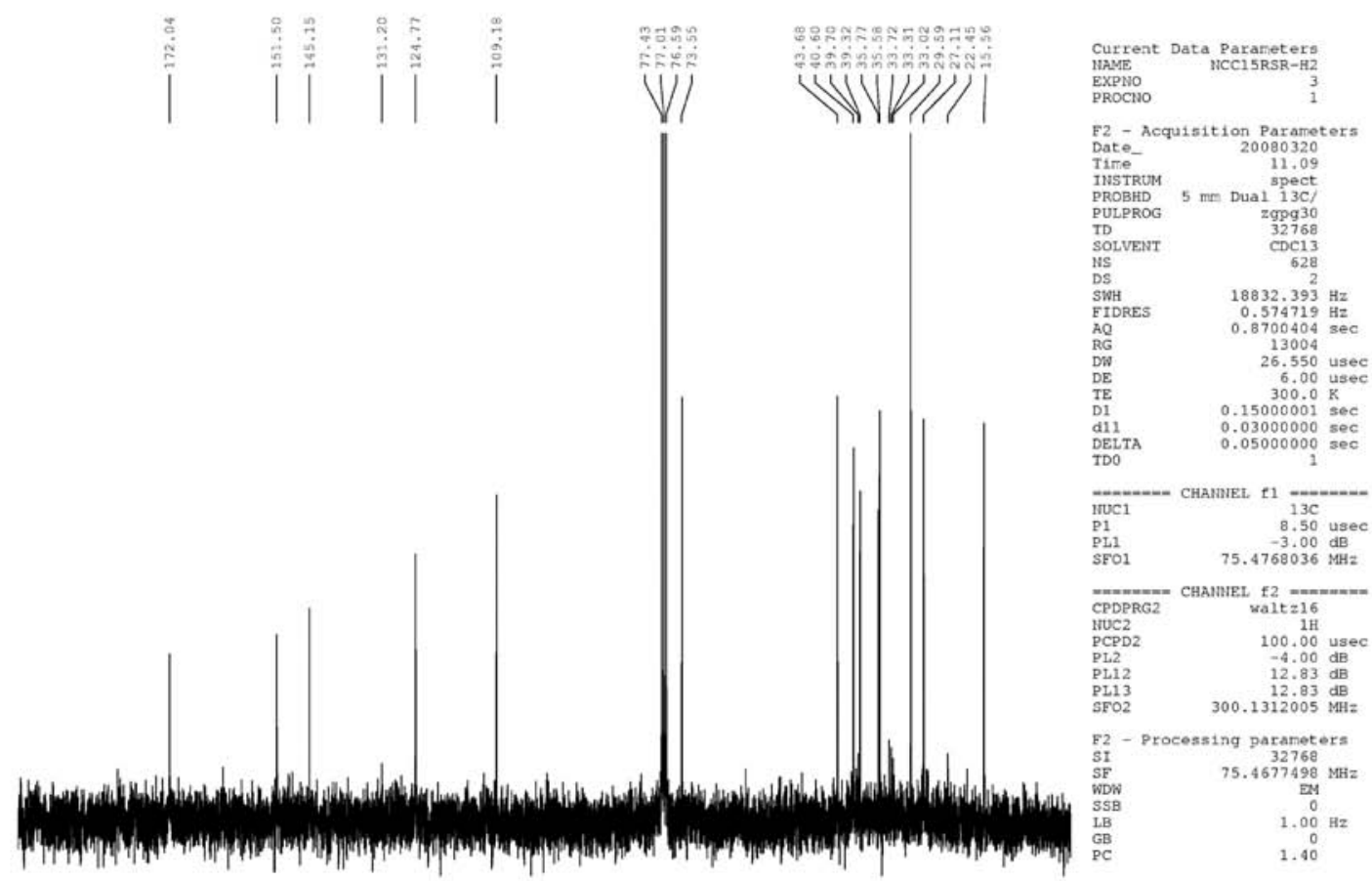

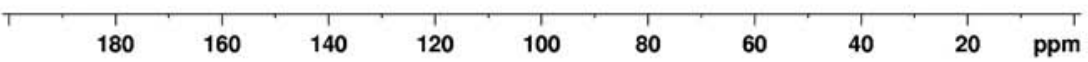

Figure 8S. ${ }^{13} \mathrm{C} \mathrm{NMR}\left(75 \mathrm{MHz}, \mathrm{CDCl}_{3}\right)$ of compound $\mathbf{3}$ (viscic acid)

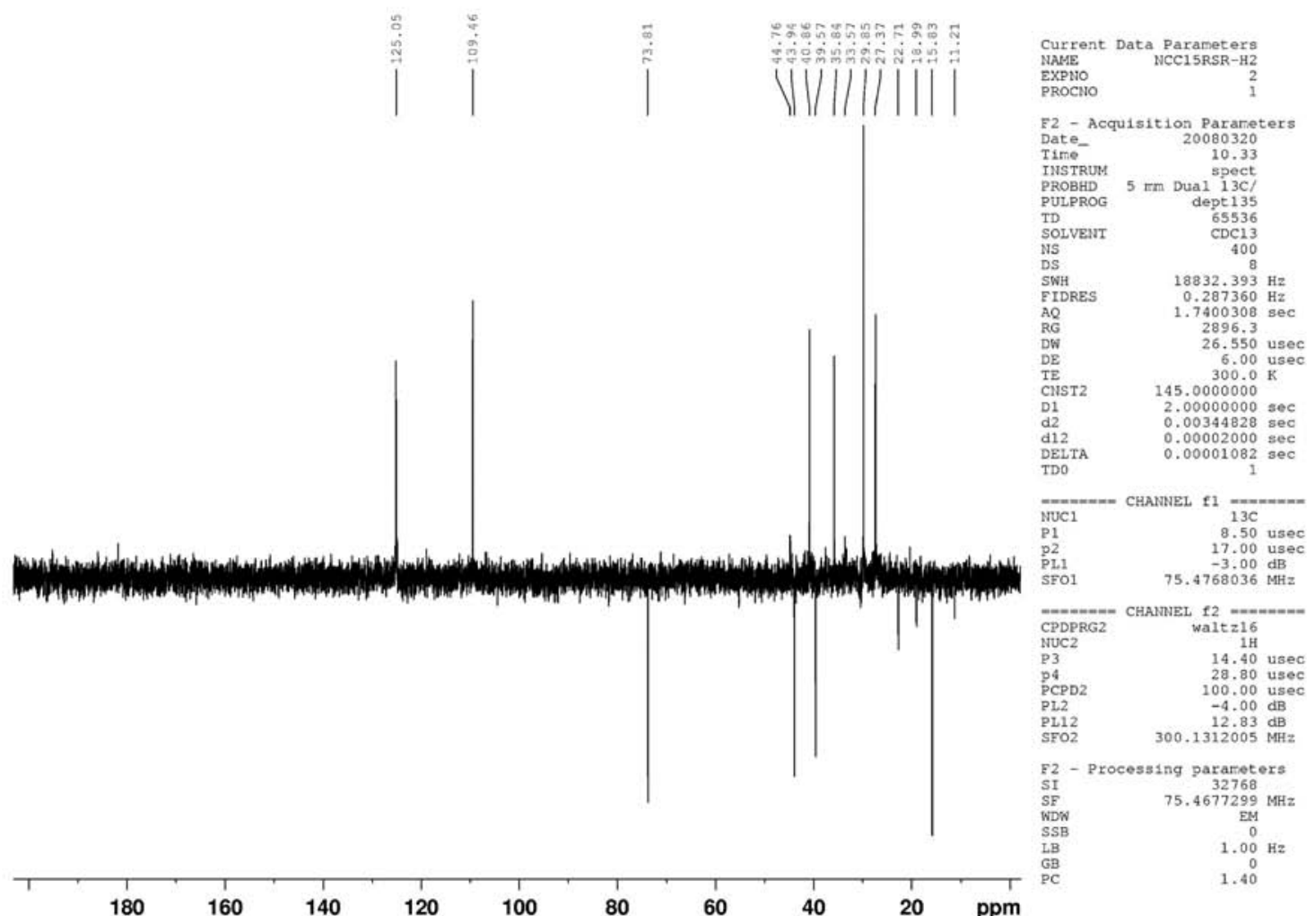

Figure 9S. DEPT $135^{\circ}\left(75 \mathrm{MHz}, \mathrm{CDCl}_{3}\right)$ of compound $\mathbf{3}$ (viscic acid) 

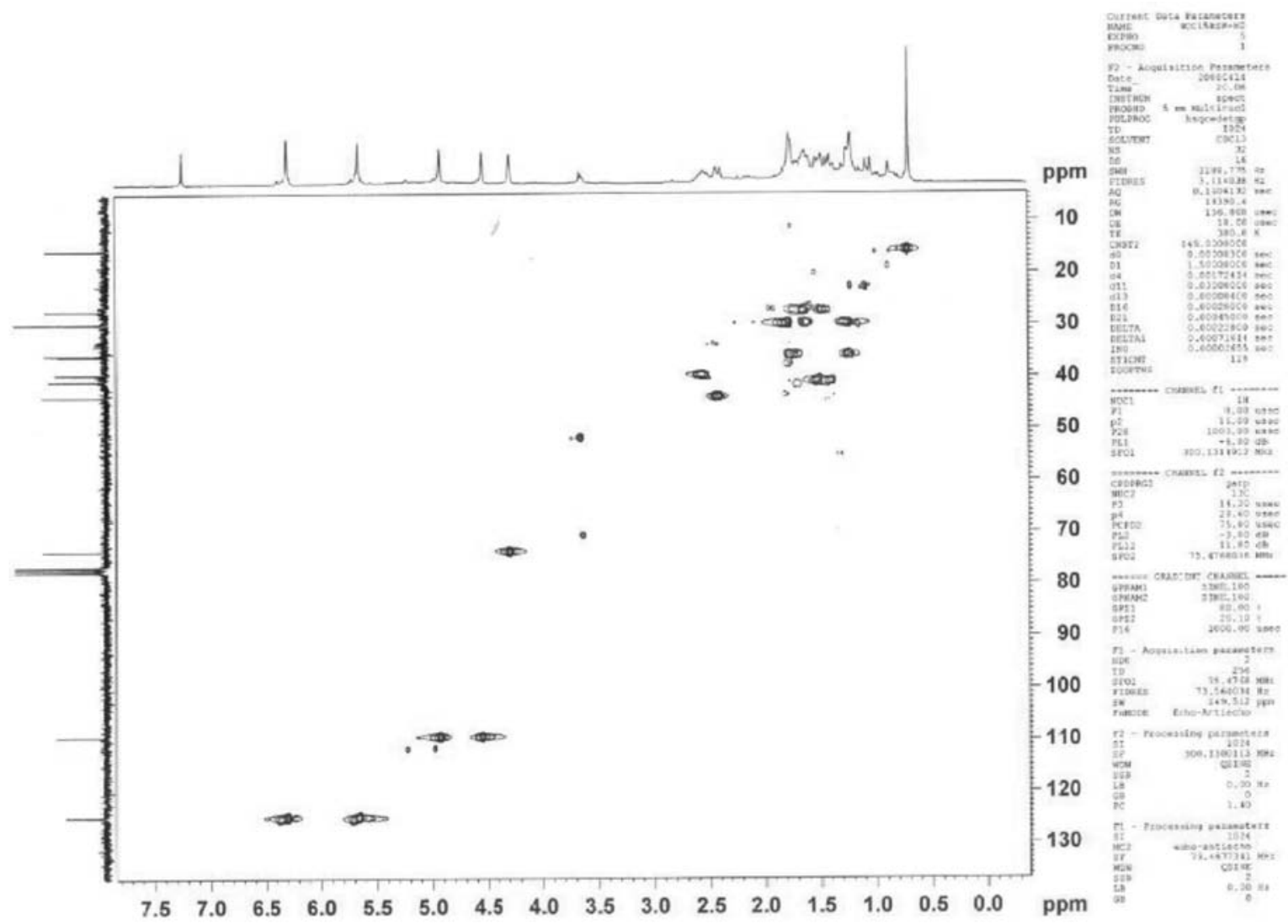

Figure 10S. $\mathrm{HSQC}\left(300 / 75 \mathrm{MHz}, \mathrm{CDCl}_{3}\right)$ of compound $\mathbf{3}$ (viscic acid)

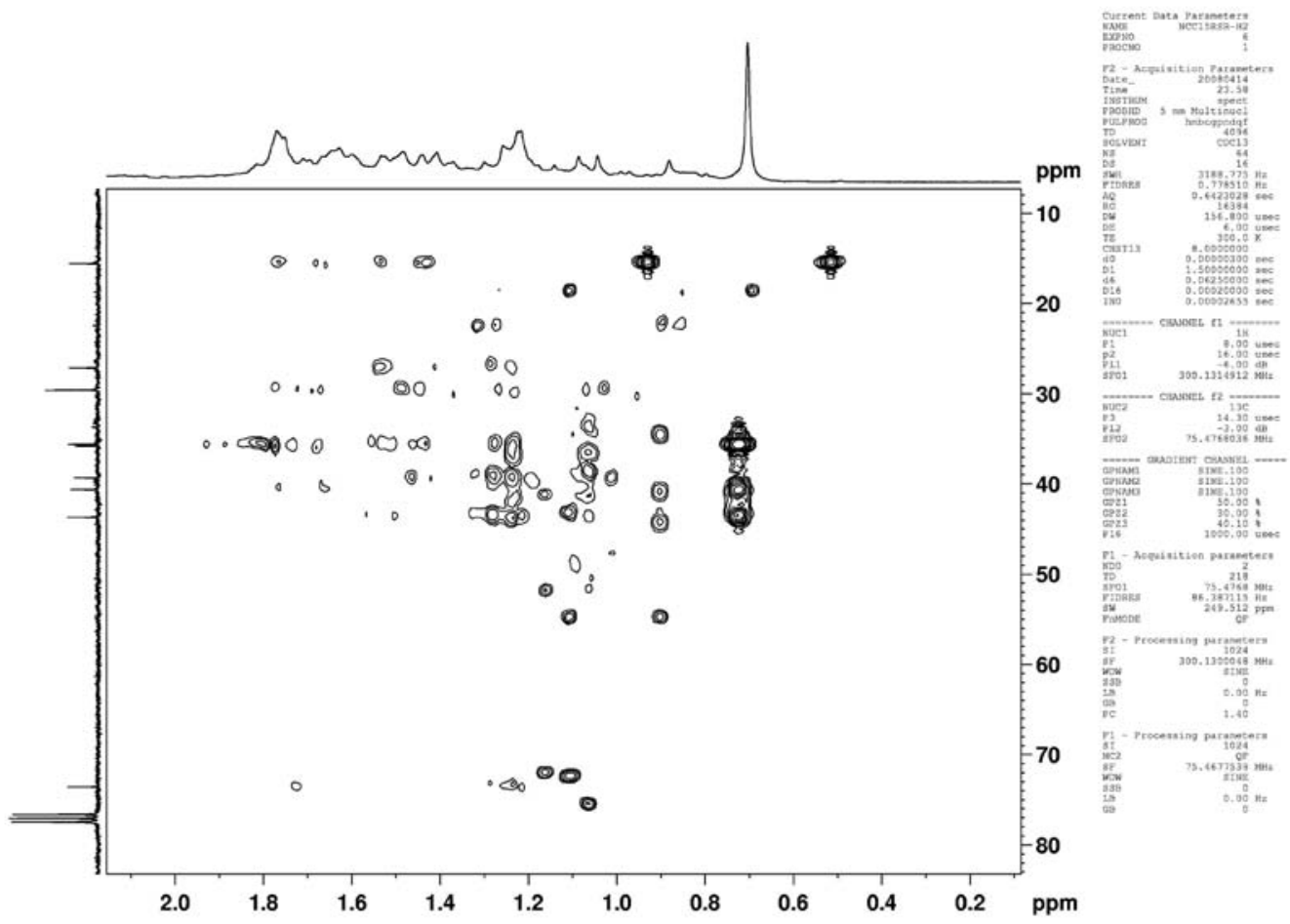

Figure 11S. $\mathrm{HMBC}\left(300 / 75 \mathrm{MHz}, \mathrm{CDCl}_{3}\right)$ of compound $\mathbf{3}$ (viscic acid) 


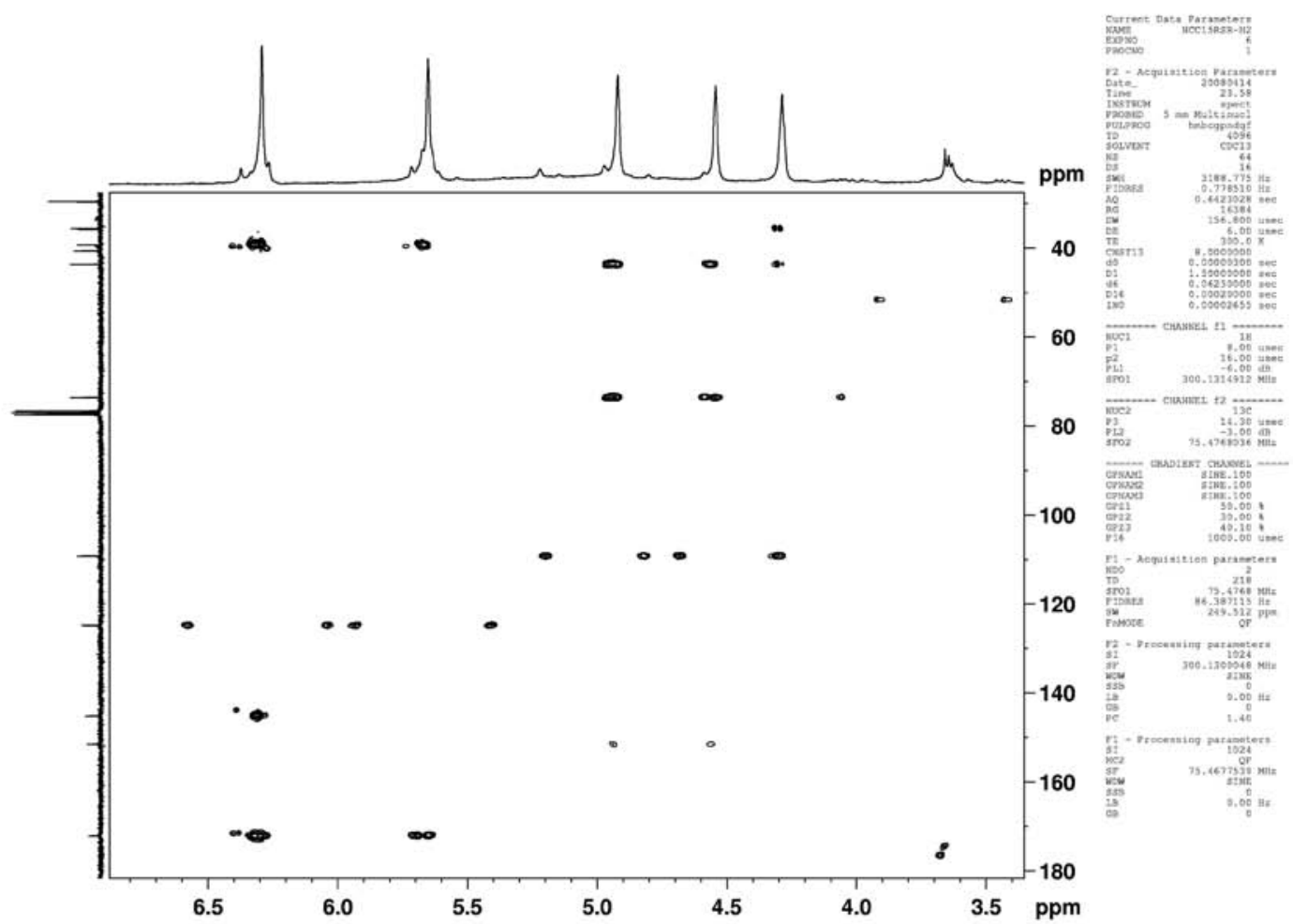

Figure 12S. $\mathrm{HMBC}\left(300 / 75 \mathrm{MHz}, \mathrm{CDCl}_{3}\right)$ of compound $\mathbf{3}$ (viscic acid)

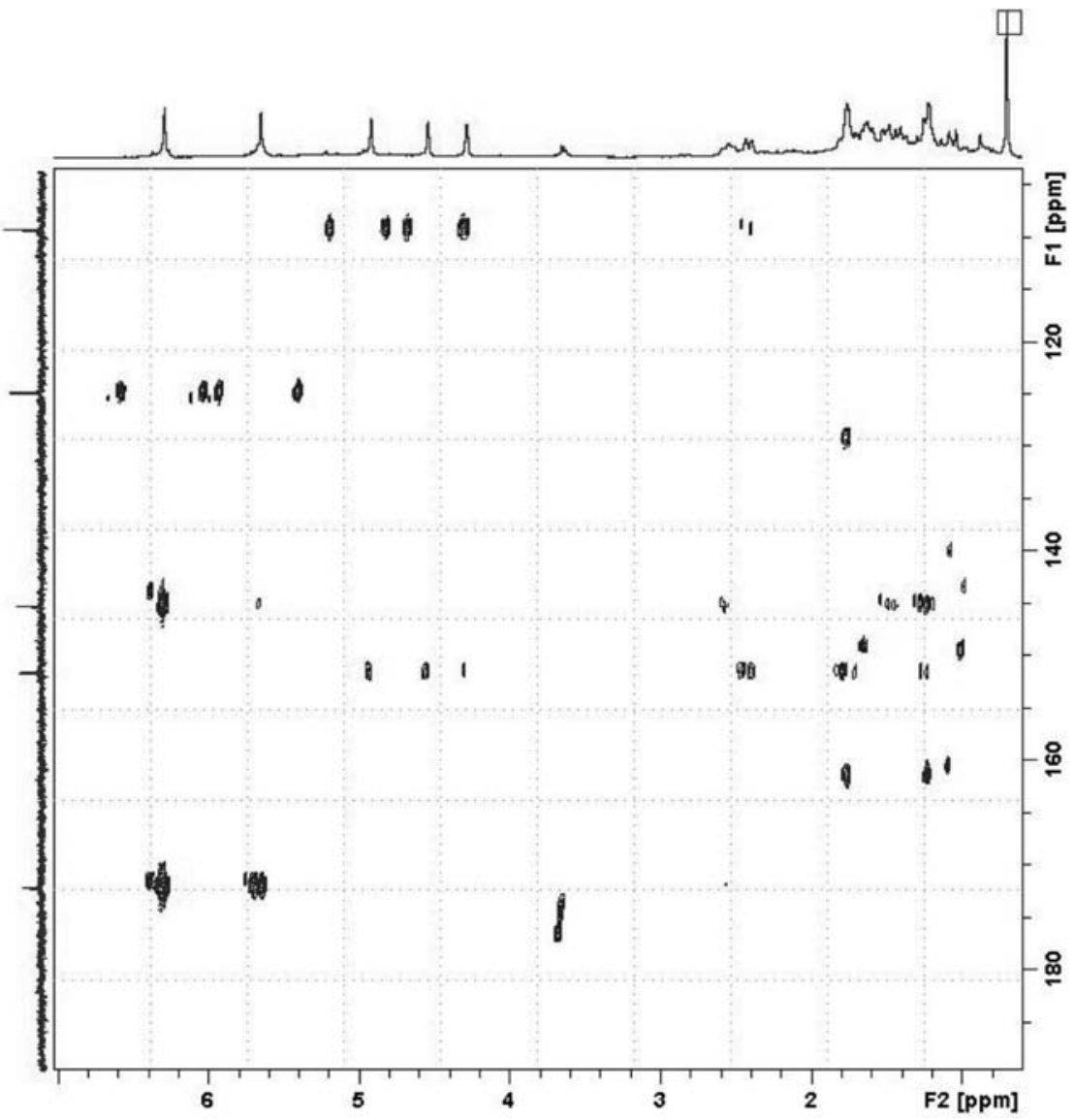

Figure 13S. $\mathrm{HMBC}\left(300 / 75 \mathrm{MHz}, \mathrm{CDCl}_{3}\right)$ of compound $\mathbf{3}$ (viscic acid) 


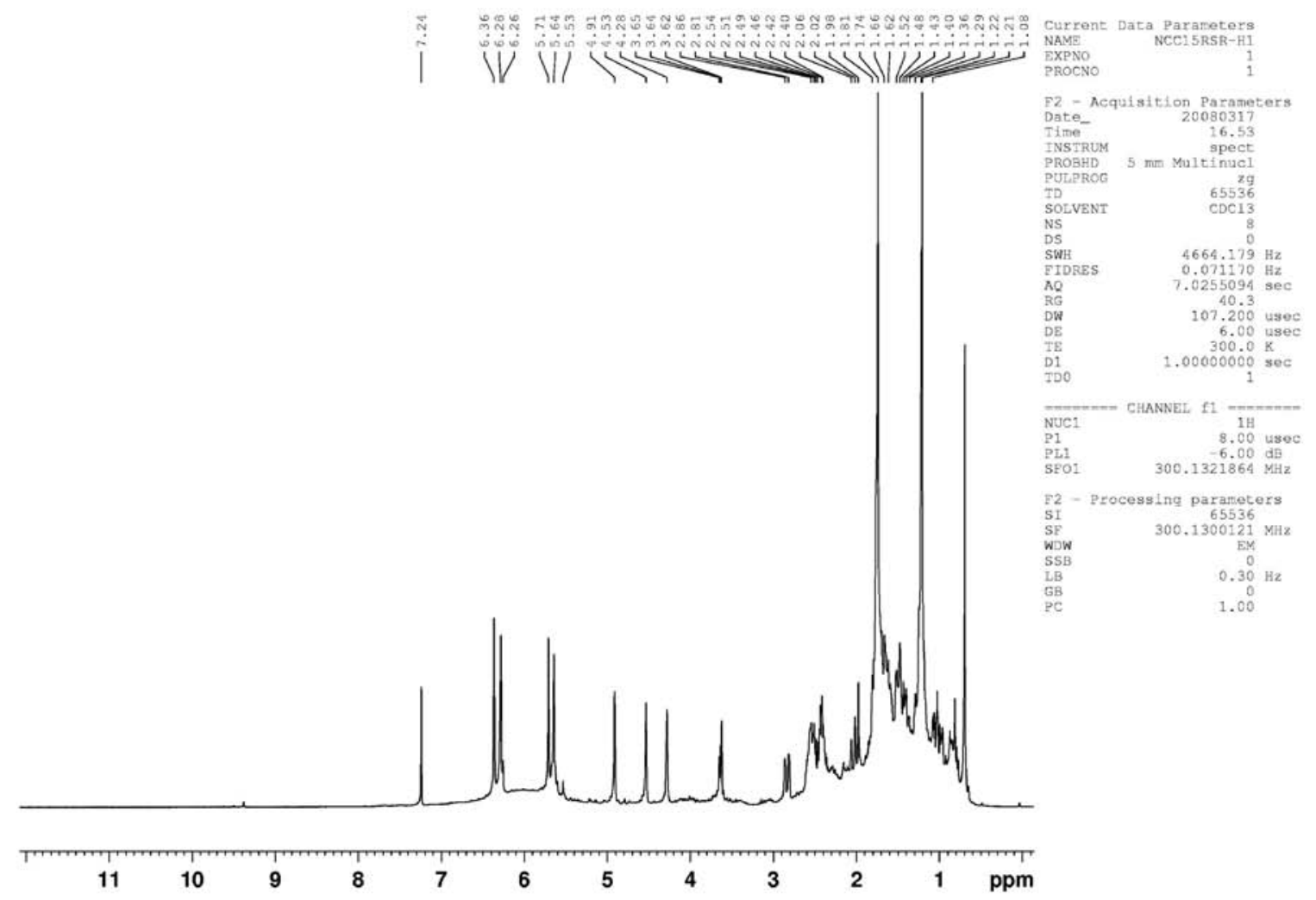

Figure 14S. ${ }^{l} \mathrm{H} N M R\left(300 \mathrm{MHz}, \mathrm{CDCl}_{3}\right)$ of compounds $\mathbf{3}+\mathbf{4}$ (3-oxo- $\gamma$-costic acid)

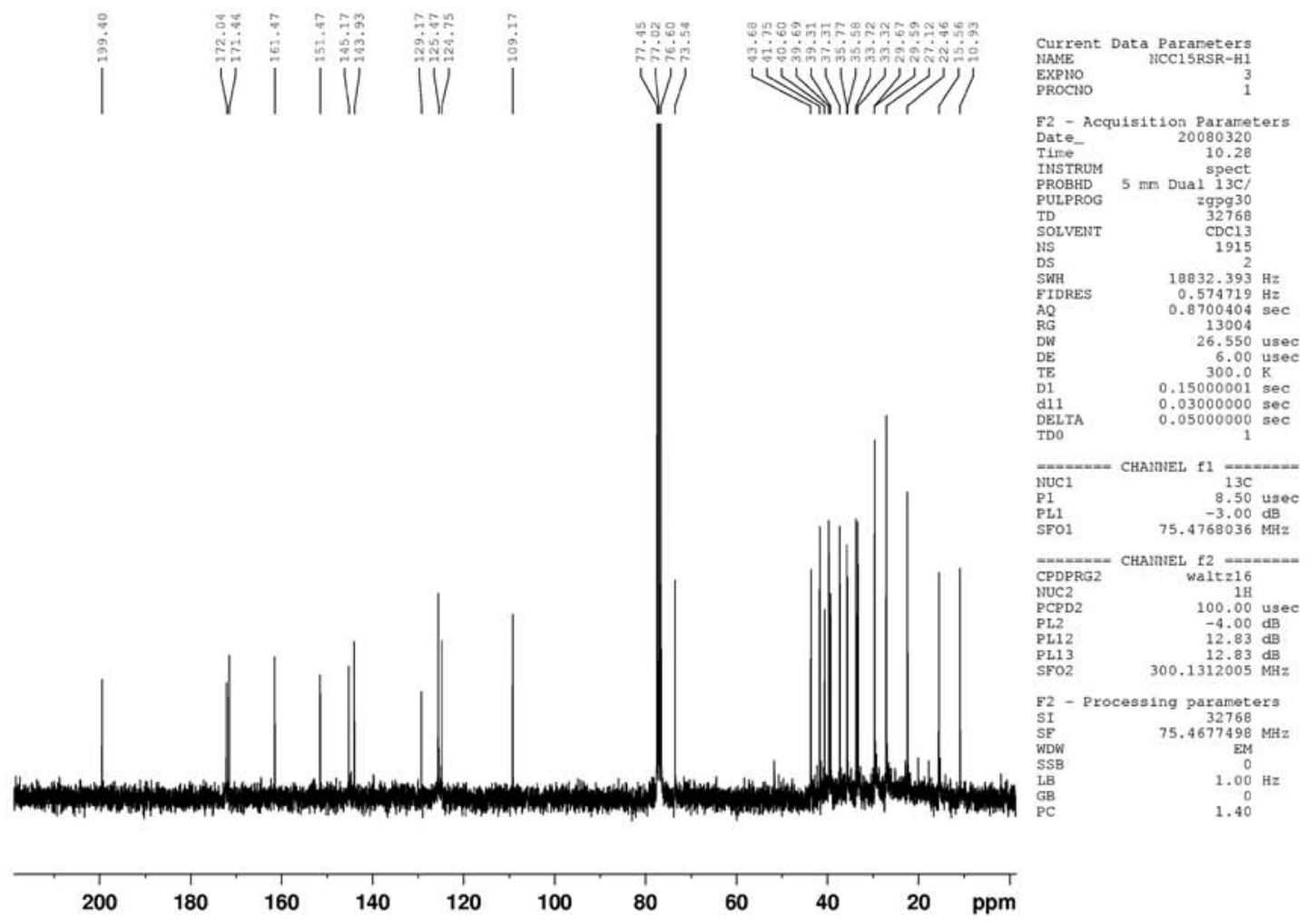

Figure 15S. ${ }^{13} \mathrm{C} \mathrm{NMR}\left(75 \mathrm{MHz}, \mathrm{CDCl}_{3}\right)$ of compounds $\mathbf{3}+\mathbf{4}$ (3-oxo- $\gamma$-costic acid) 


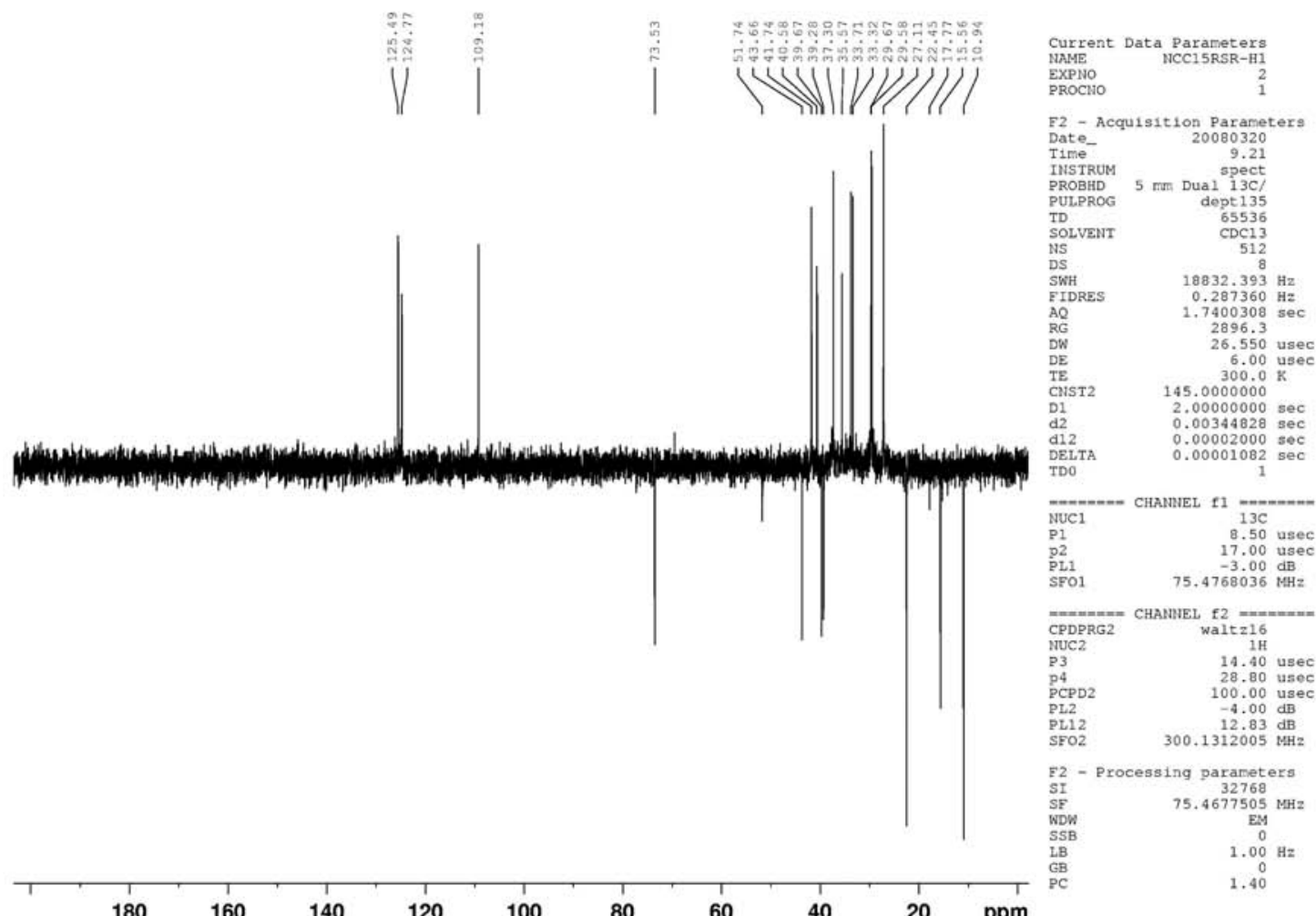

Figure 16S. $D E P T 135^{\circ}\left(75 \mathrm{MHz}, \mathrm{CDCl}_{3}\right)$ of compounds $\mathbf{3}+\mathbf{4}$ (3-oxo- $\gamma$-costic acid)
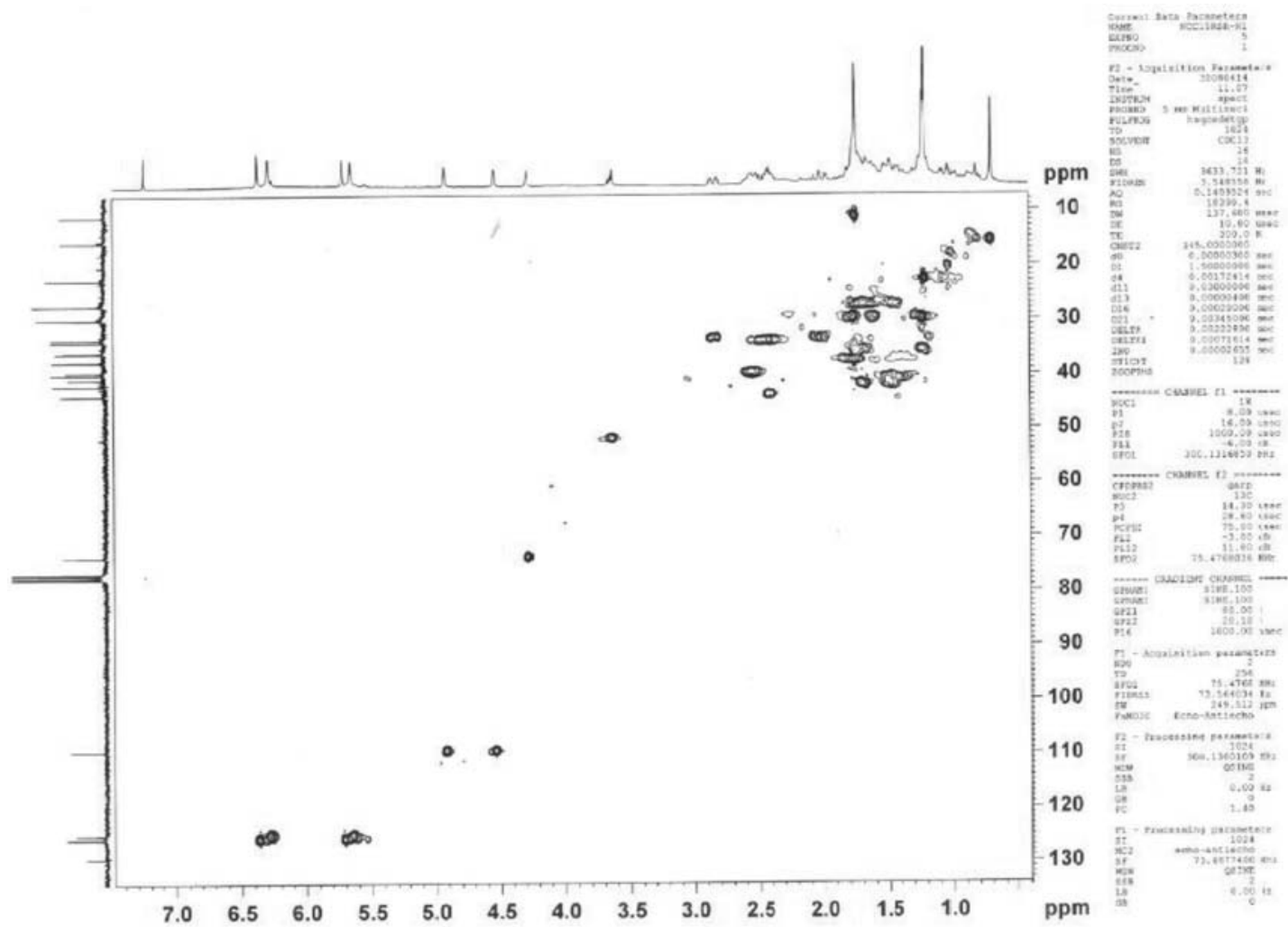

Figure 17S. $\mathrm{HSQC}\left(300 / 75 \mathrm{MHz}, \mathrm{CDCl}_{3}\right)$ of compounds $\mathbf{3}+\mathbf{4}$ (3-oxo- $\gamma$-costic acid) 


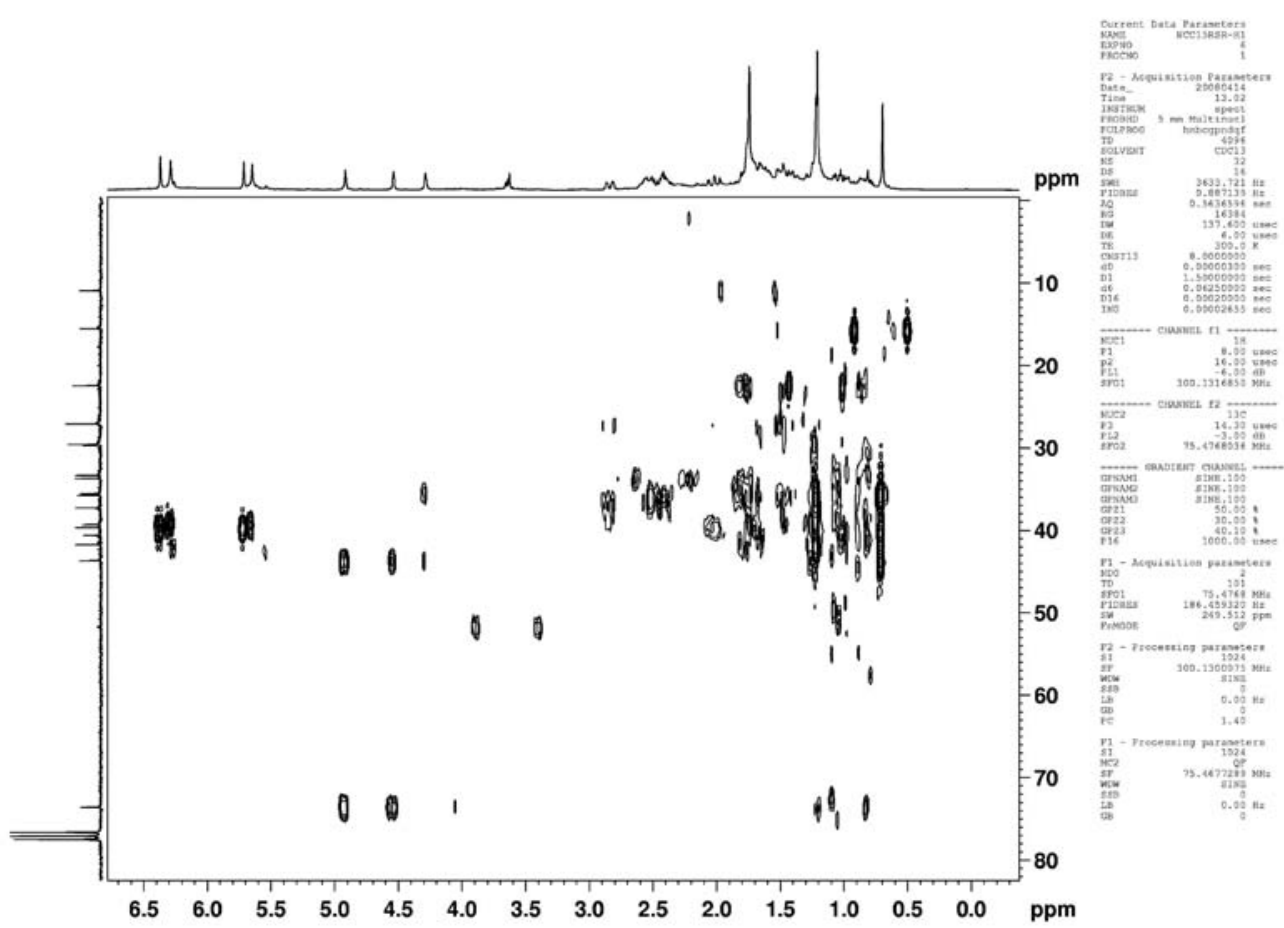

Figure 18S. $\mathrm{HMBC}\left(300 / 75 \mathrm{MHz}, \mathrm{CDCl}_{3}\right)$ of compounds $\mathbf{3}+\mathbf{4}$ (3-oxo- $\boldsymbol{\gamma}$-costic acid)

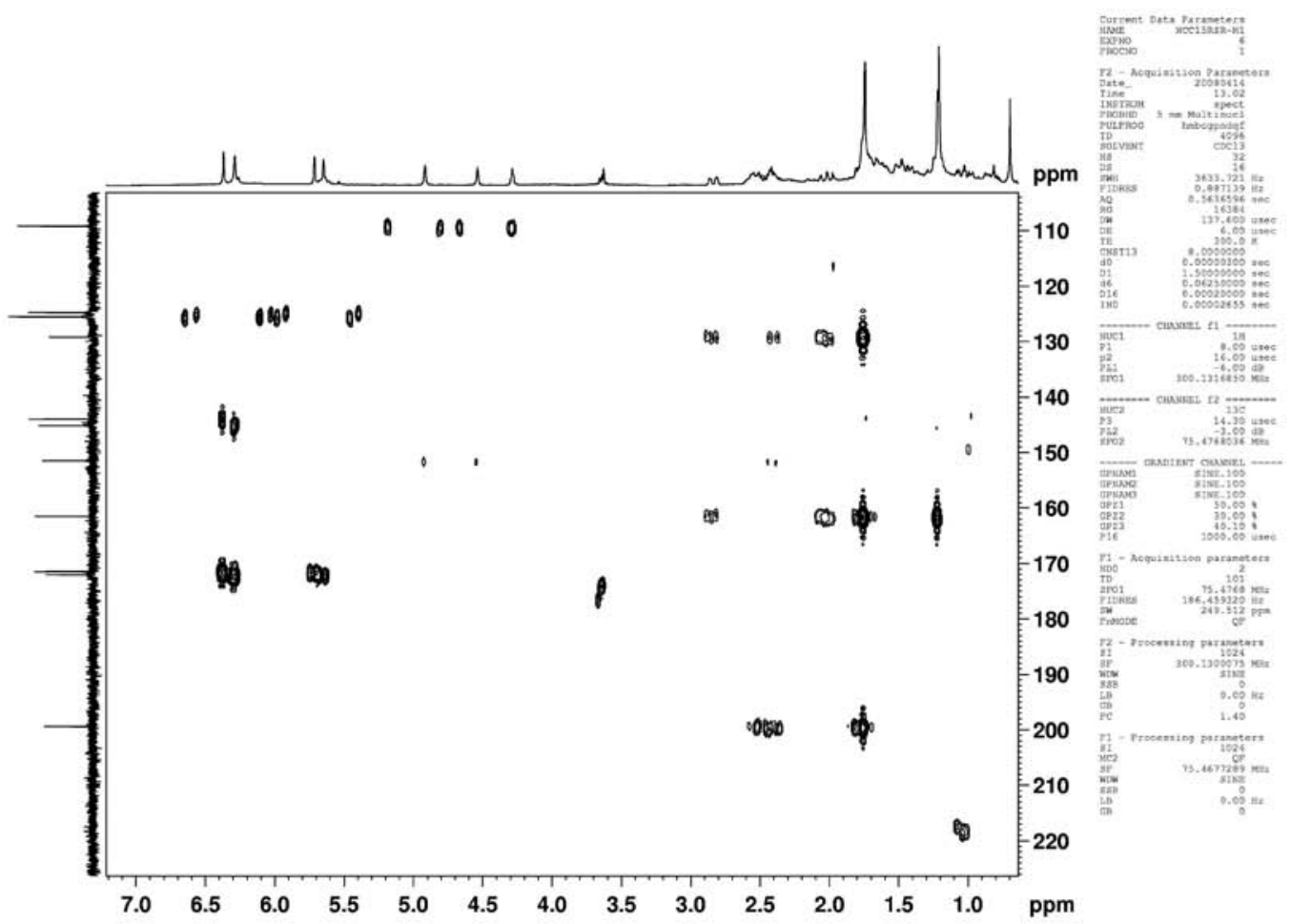

Figure 19S. $\mathrm{HMBC}\left(300 / 75 \mathrm{MHz}, \mathrm{CDCl}_{3}\right)$ of compounds $\mathbf{3}+\mathbf{4}$ (3-oxo- $\gamma$-costic acid) 


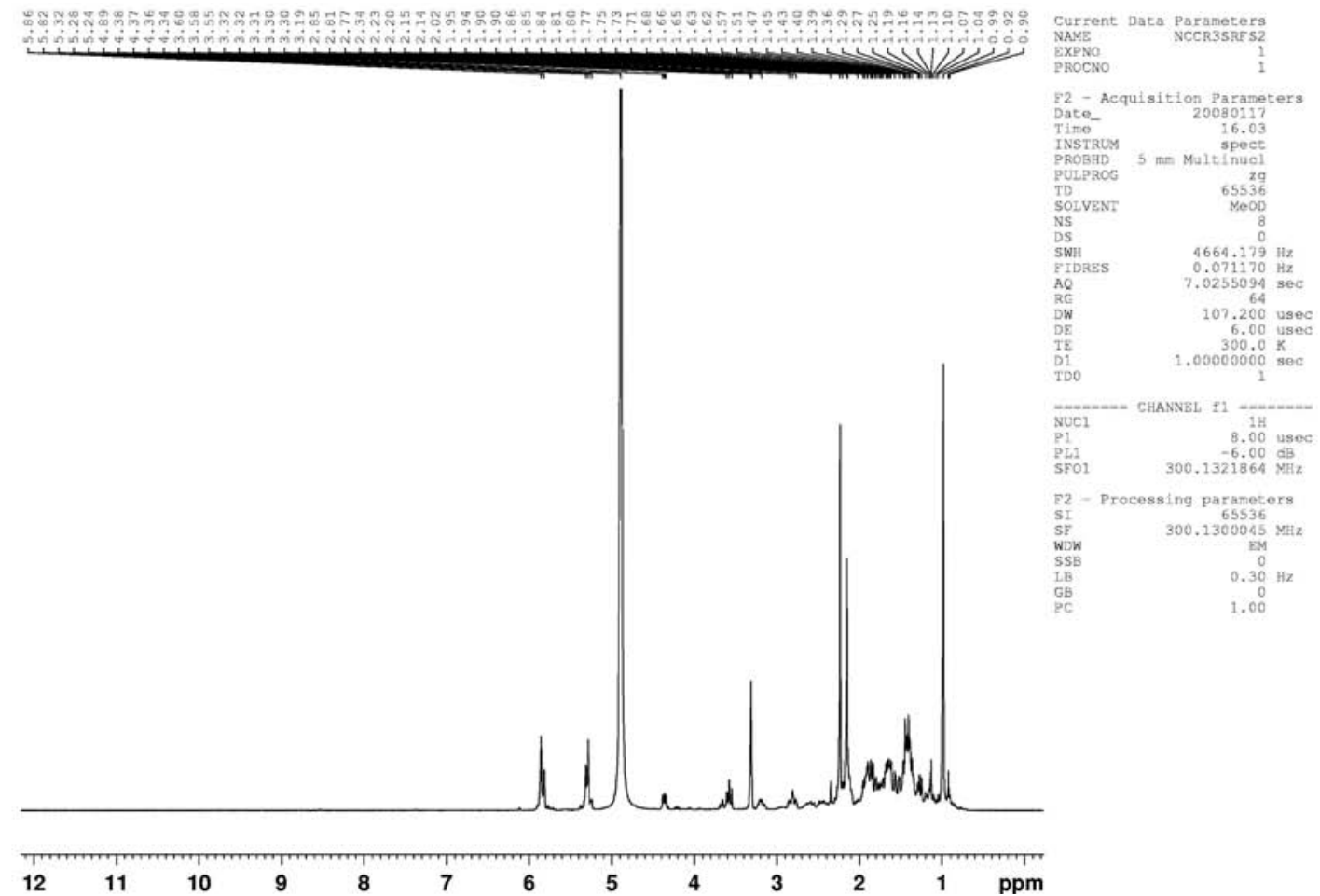

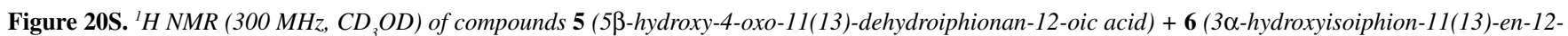
oic acid)

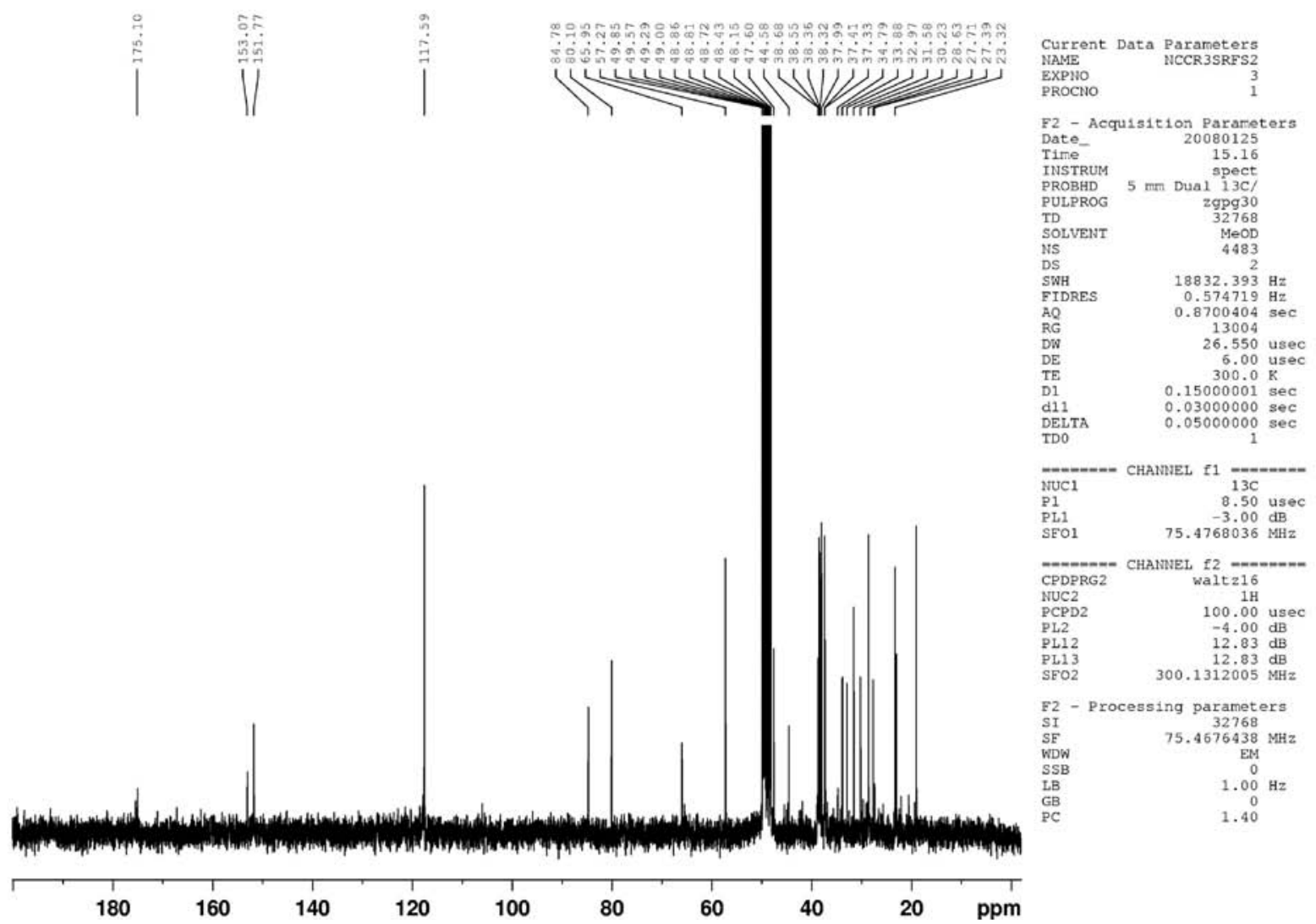

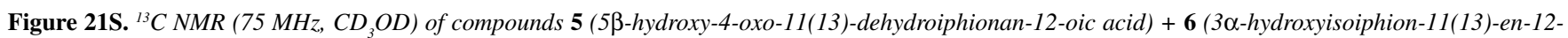
oic acid) 


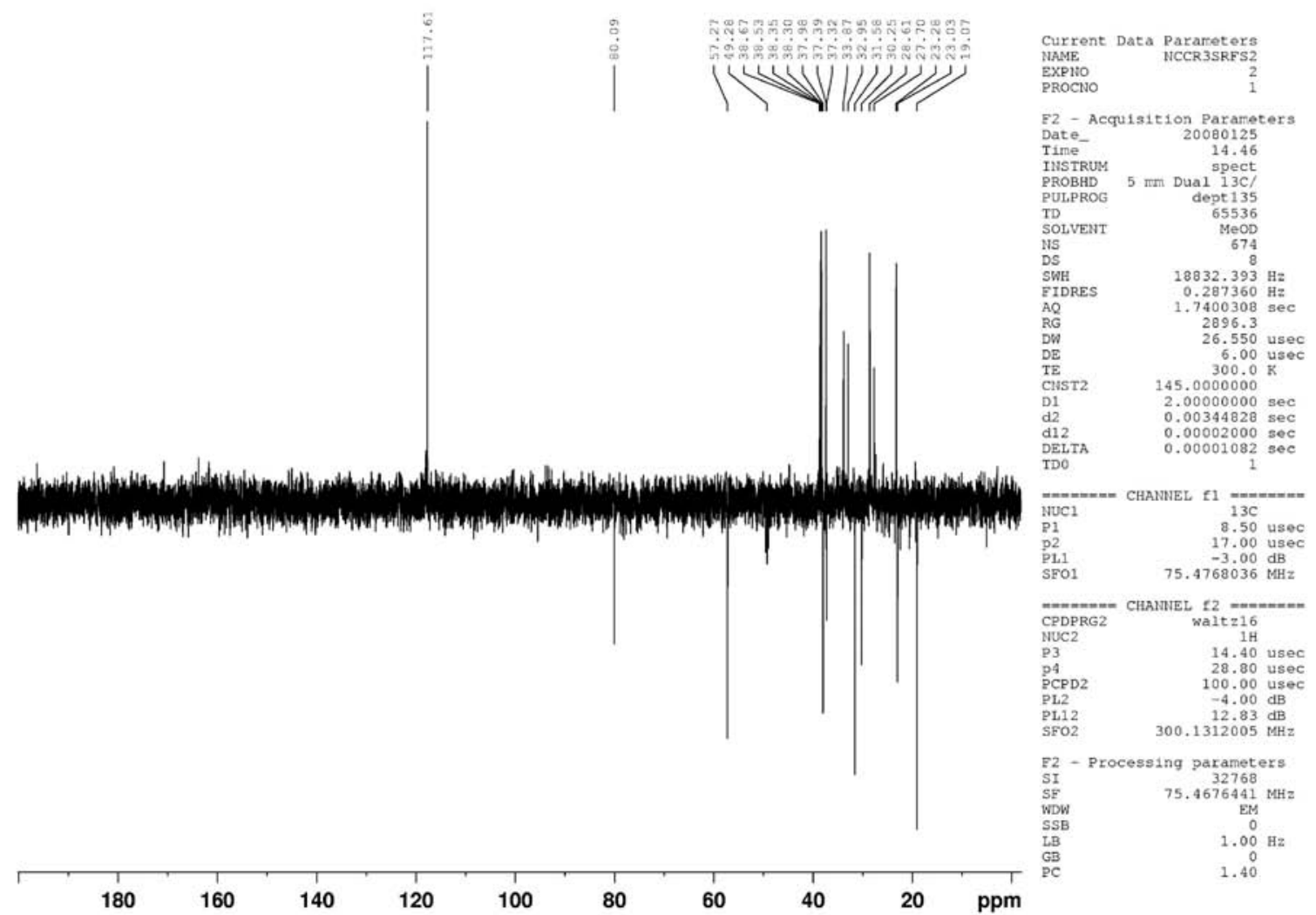

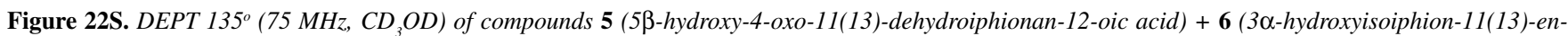
12-oic acid)

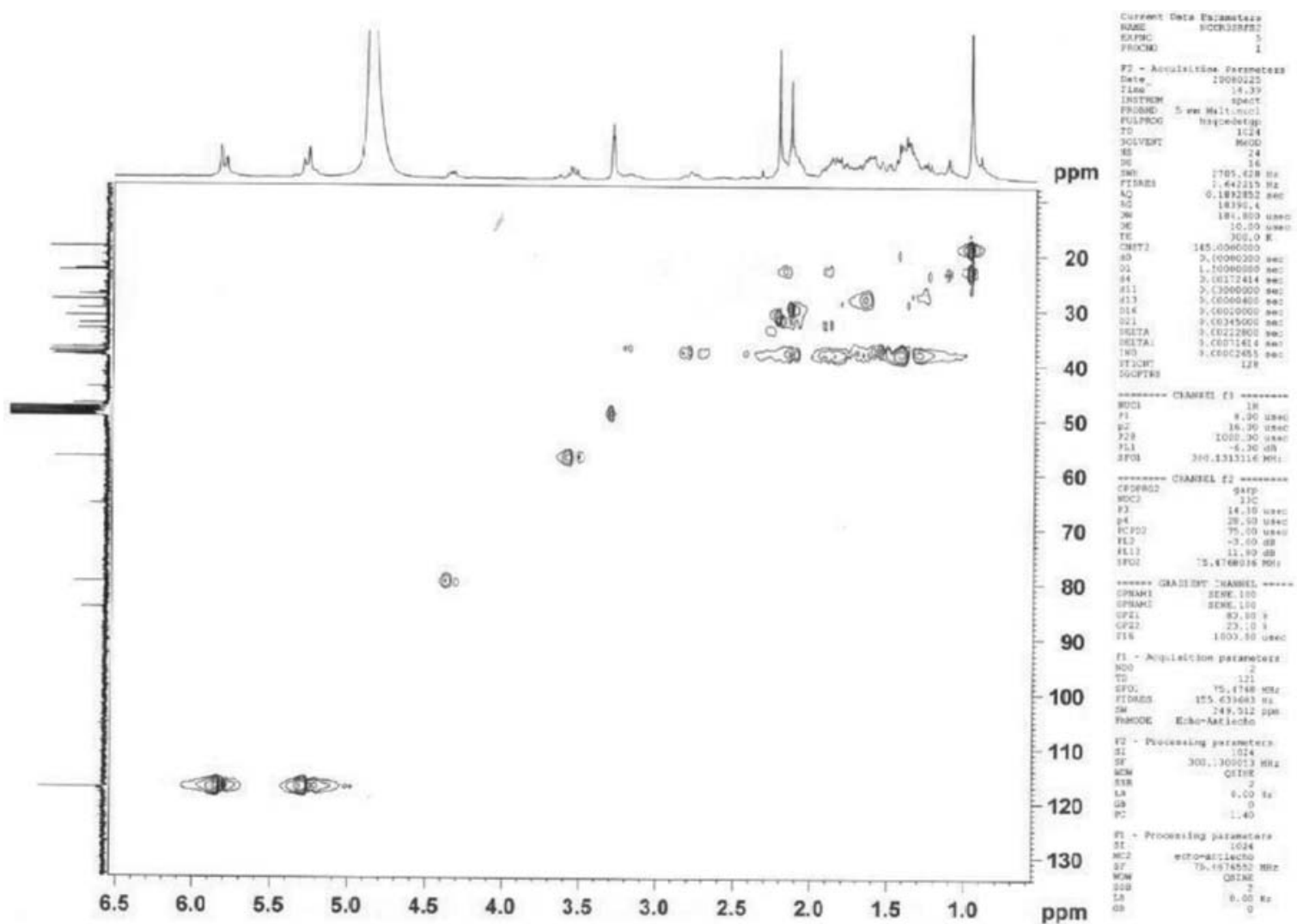

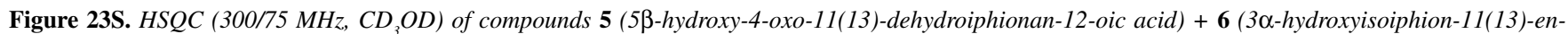
12-oic acid) 


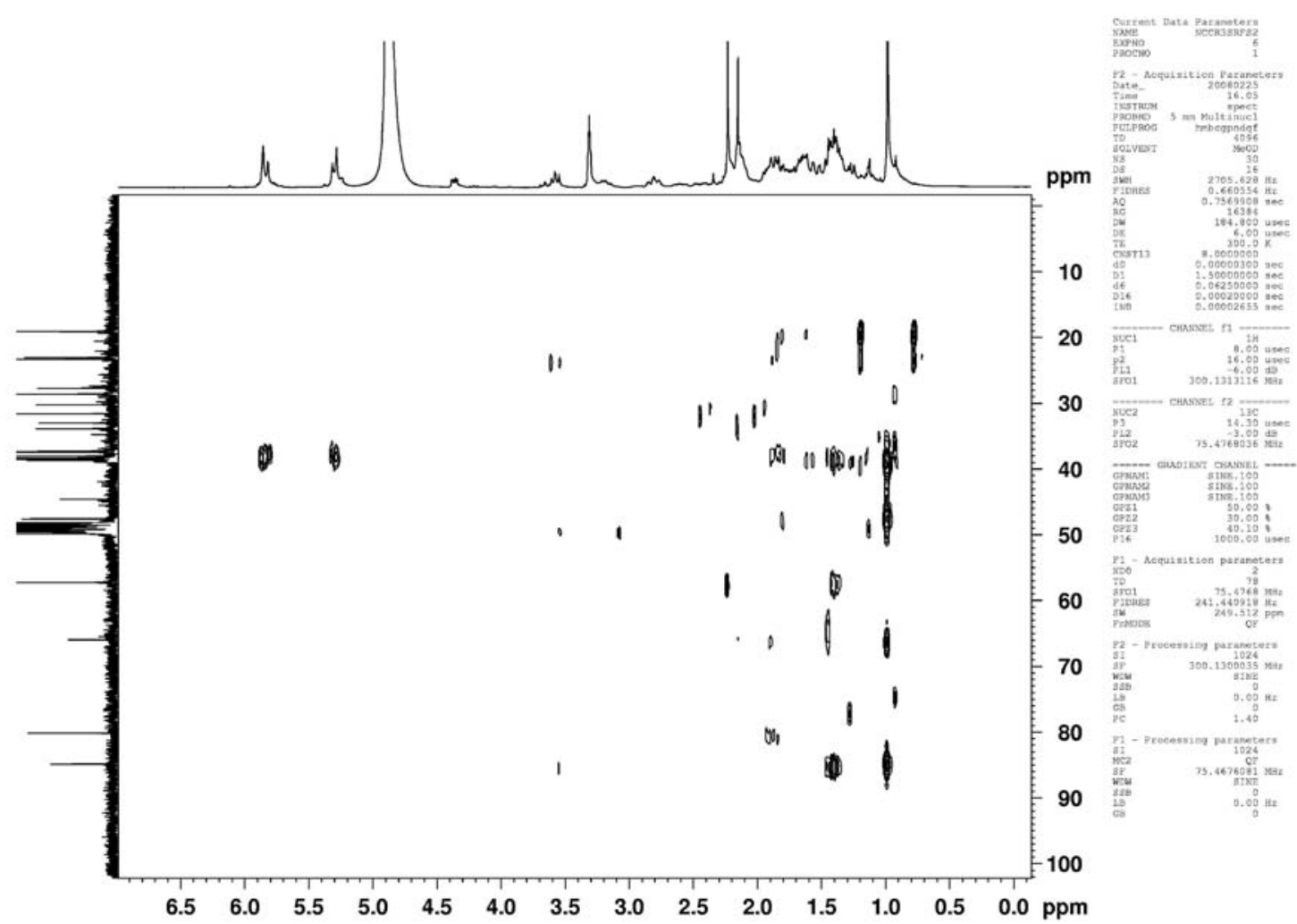

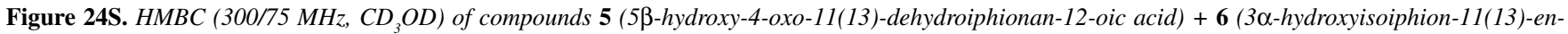
12-oic acid)

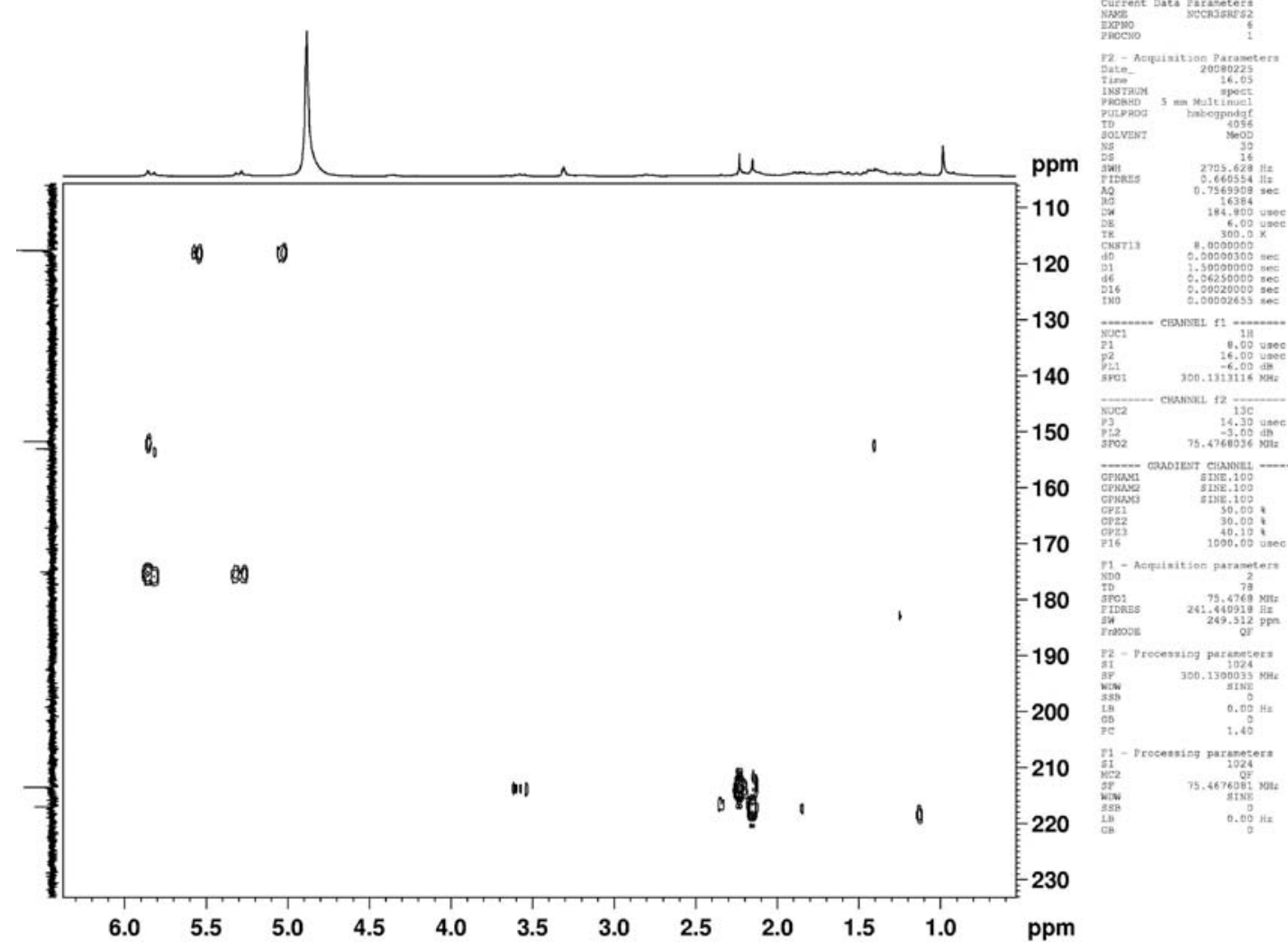

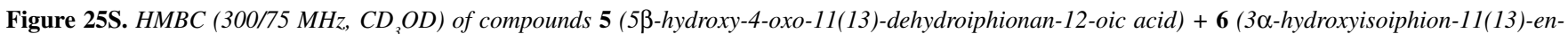
12-oic acid 